\title{
34. ORGANOFACIES RECONSTRUCTION AND LIPID GEOCHEMISTRY OF SEDIMENTS FROM THE GALICIA MARGIN, NORTHEAST ATLANTIC (ODP LEG 103) ${ }^{1}$
}

\author{
Rüdiger Stein, Institut für Geowissenschaften und Lithosphärenforschung, Universität Giessen, Giessen, Federal \\ Republic of Germany \\ and \\ Jürgen Rullkötter, Ralf Littke, Rainer G. Schaefer, and Dietrich H. Welte, Institut für Erdöl und Organische \\ Geochemie, Jülich, Federal Republic of Germany
}

\begin{abstract}
Samples of Lower to middle Cretaceous rocks from ODP Sites 638, 640, and 641, drilled on the Galicia continental margin in the northeast Atlantic, have been investigated by organic geochemical methods (i.e., organic carbon determination, Rock-Eval pyrolysis, kerogen microscopy, gas chromatography, and gas chromatography/mass spectrometry) to define the organofacies types and the depositional environments of these sediments. The results of this study fit well into the general picture drawn for the depositional history of the organic matter in Cretaceous organic-carbon-rich sediments in the North Atlantic from previous DSDP investigations.

During the Valanginian to Albian, terrigenous organic carbon dominated the organic matter deposited on the Galicia continental margin. Cyclic changes in total organic carbon content were probably controlled by climatic-triggered changes in the supply of terrigenous organic matter from the nearby continent. A drastic change in depositional environment must have occurred near the Cenomanian/Turonian boundary. The preservation of large amounts of marine organic carbon in these sediments was probably caused by anoxic deep-water conditions during that time, rather than high productivity.

All of the primary organic matter of the sediment samples investigated is thermally immature, as indicated by very low vitrinite reflectance values.
\end{abstract}

\section{INTRODUCTION}

During Ocean Drilling Program (ODP) Leg 103, a transect of sites was drilled on the Galicia continental margin off Portugal in the northeastern Atlantic. A major objective of this leg was to extend the results of Deep Sea Drilling Project (DSDP) Leg 47B, Site 398 (Fig. 1; Sibuet, Ryan, et al., 1979), by coring a continuous record of Lower Cretaceous to Upper Jurassic synrift and possibly pre-rift sediments and the top of the underlying basement (Shipboard Scientific Party, 1987a, 1987b, 1987c).

This study concentrates on the organic matter from middle and Lower Cretaceous sediments at Sites 638, 640, and 641 (Fig. 1 and Table 1). To determine organofacies types as indicators for depositional environments, 25 samples were collected for detailed investigations of geochemistry and petrography of the organic matter.

\section{METHODS}

The frozen samples were dried at $50^{\circ} \mathrm{C}$ for $12 \mathrm{hr}$ and then ground. From these prepared samples, total carbon (TC) was determined using a LECO IR-112 carbon analyzer. Total organic carbon (TOC) was determined with the same LECO carbon analyzer after treatment of the sediments with hydrochloric acid to remove the carbonate carbon. The inorganic carbon (IC) was calculated by difference

$$
\operatorname{IC}(\%)=\operatorname{TC}(\%)-\operatorname{TOC}(\%),
$$

and the carbonate content was calculated as

$$
\mathrm{CaCO}_{3}(\%)=\mathrm{IC}(\%) \times 8.33 \text {. }
$$

Extraction was performed using a modified flow-blending technique (Radke et al., 1978) with dichloromethane as the extraction solvent. The

${ }^{1}$ Boillot, G., Winterer, E. L., et al., 1988. Proc. ODP, Sci. Results, 103: College Station, TX (Ocean Drilling Program). total extracts were separated into nonaromatic hydrocarbons, aromatic hydrocarbons, and heterocomponents by automated medium-pressure liquid chromatography (Radke et al., 1980).

A Siemens L350 gas chromatograph equipped with a $2.5 \mathrm{~m} \times 0.3-$ mm-ID glass capillary column coated with SE5 was used for gas chromatographic analysis of the nonaromatic hydrocarbon fractions. Helium was used as the carrier gas. The temperature program was programmed from $80^{\circ}$ to $285^{\circ} \mathrm{C}$ at a rate of $3^{\circ} \mathrm{C} / \mathrm{min}$; isothermal was at a temperature of $220^{\circ} \mathrm{C}$ for $25 \mathrm{~min}$.

Gas chromatography/mass spectrometry of extractable hydrocarbons was carried out only for the five most organic-carbon-rich samples, which also yielded the highest extract quantities. The VG 7070E mass spectrometer was linked directly to a Carlo Erba Fractovap model $\mathbf{4 1 6 0}$ gas chromatograph via an open-split coupling. Samples were injected splitless onto a $25 \mathrm{~m} \times 0.3-\mathrm{mm}$-ID fused silica column coated with SE54. Helium was used as the carrier gas, and the temperature was programmed from $70^{\circ}$ to $300^{\circ} \mathrm{C}$ at a rate of $3^{\circ} \mathrm{C} / \mathrm{min}$. The mass spectrometer was operated at an ionization energy of $70 \mathrm{eV}$. The source temperature was kept at $220^{\circ} \mathrm{C}$, and the magnet scanned continuously at a rate of $3 \mathrm{~s} / \mathrm{scan}$. All data were stored and processed using a DS $55 \mathrm{C}$ on-line Kratos AEI data system.

Rock-Eval pyrolysis was performed according to the method described by Espitalié et al. (1977). Hydrogen and oxygen contents of the sediment samples, measured as hydrocarbon-type compound and carbon dioxide yields, respectively, were normalized to organic carbon and shown as index values in a van Krevelen diagram.

The kerogen-separation procedure included treatment with $7.5 \mathrm{~N}$ $\mathrm{HCl}$ and $\mathrm{HF}$. The maceral types were analyzed using both transmitted and normal or fluorescent reflected light. Vitrinite reflectance (at 546 $\mathrm{nm}$ in oil) was measured on particles larger than $100 \mu \mathrm{m}$.

Because changes in the percent values of TOC can result from changes in the abundance of both mineral components and organic carbon, the percent values were transformed into accumulation rates, following van Andel et al. (1975). Linear sedimentation rates and physicalproperty data required for calculation of these accumulation rates were derived from Leg 103 data (Shipboard Scientific Party, 1987a, 1987b). The amount of marine organic carbon (cf. Stein et al., 1986) was estimated from kerogen microscopy data and used as a basis for establish- 
A

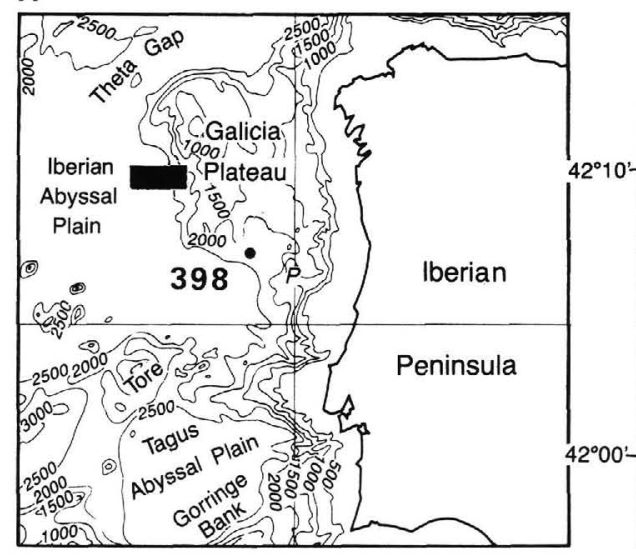

B

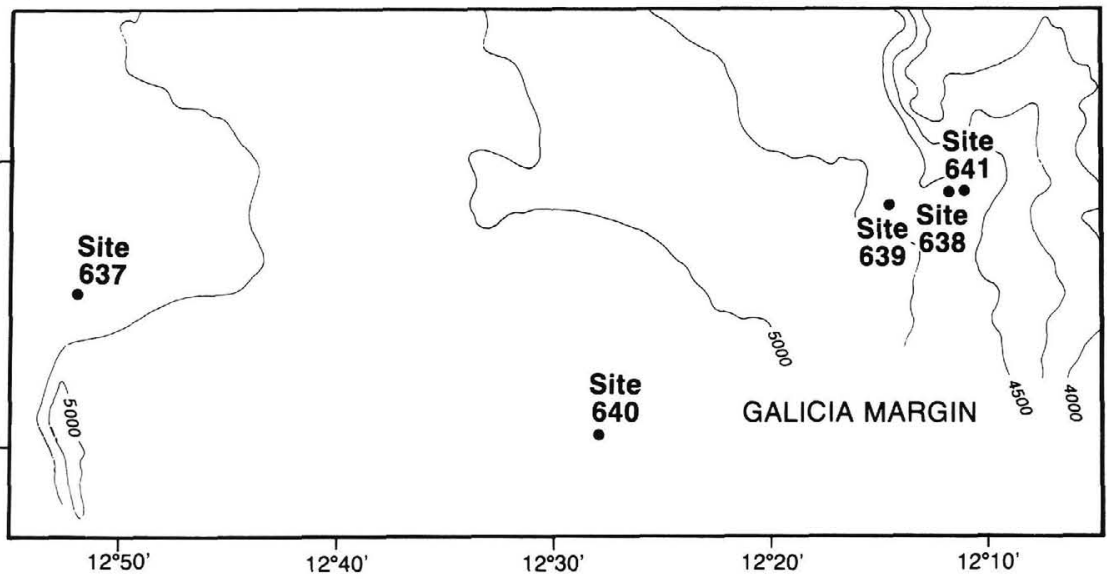

Figure 1. A. General location map of Galicia margin showing DSDP Site 398. Boxed area shown in Figure 1B. B. Sea Beam bathymetric map with locations of ODP Sites 637-641. Bathymetric contours in meters.

Table 1. Sub-bottom depths, ages, and lithology of samples investigated.

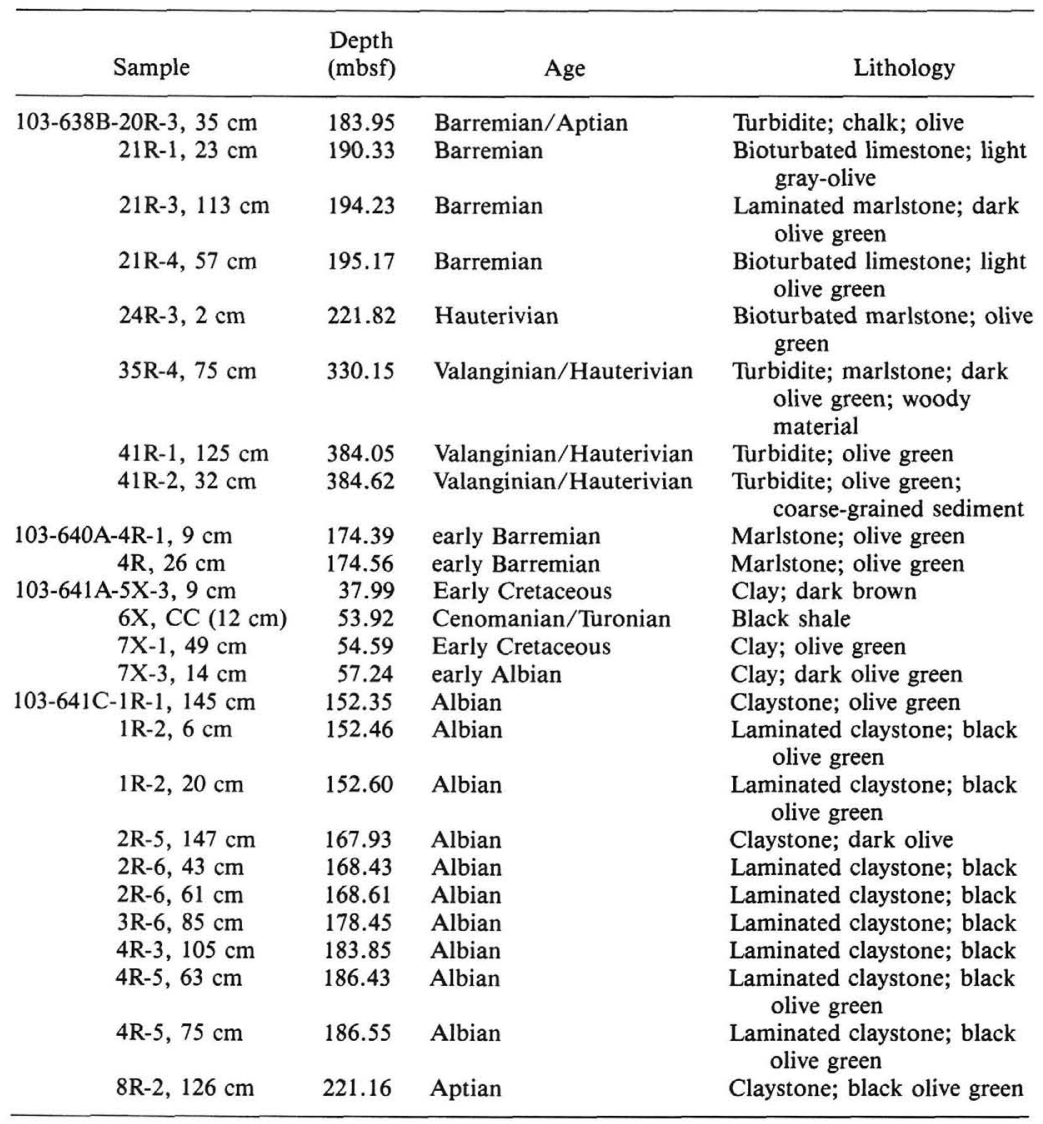

ing paleoproductivity values. These estimates of paleoproductivity in the Mesozoic Atlantic Ocean are based on comparisons with modern environments (Müller and Suess, 1979; Betzer et al., 1984; Bralower and Thierstein, 1984). For oxic environments, we have used equation (1), which is based on Müller and Suess (1979) and Betzer et al. (1984); for anoxic environments, we have used equation (2), which is according to Bralower and Thierstein (1984):

$$
\begin{aligned}
\mathrm{PR}= & 5.31 \times\left(\mathrm{C} \times\left[\mathrm{WBD}-1.026 \times \mathrm{PO} \times 10^{-2}\right]\right)^{0.71} \\
& \times \mathrm{SR}^{0.07} \times \mathrm{DEP}^{0.45}
\end{aligned}
$$

$$
\mathrm{PR}=5 \times \mathrm{C} \times \mathrm{SR} \times\left(\mathrm{WBD}-1.026 \times \mathrm{PO} \times 10^{-2}\right)
$$

where $\mathrm{PR}=$ paleoproductivity in $\mathrm{gC} / \mathrm{m}^{2} / \mathrm{yr}, \mathrm{C}=$ marine organic carbon in $\mathrm{wt} \%$, WBD = wet-bulk density in $\mathrm{g} / \mathrm{cm}^{3}, \mathrm{PO}=$ porosity in $\%$, $\mathrm{SR}=$ sedimentation rate in $\mathrm{cm} / 1000 \mathrm{yr}$, and $\mathrm{DEP}=$ water depth at that time in $\mathrm{m}$. The detailed deduction of equation (1) is published in Stein (1986b). Diagenetic losses of organic matter (up to approximately $30 \%$; Raiswell and Berner, 1987) are not considered in the calculated productivity values. This means that the estimates of paleoproductivity may be somewhat low. 


\section{RESULTS}

\section{Total Organic Carbon and Carbonate Carbon}

Most of the sediment sections investigated are characterized by organic carbon contents distinctly higher than those observed in most modern open-marine environments (Table 2).

At Site 638, organic carbon values of Lower Cretaceous sediments range between $0.1 \%$ and $2.2 \%$, with TOC values of less than $1 \%$ prevalent (Fig. 2). Maximum values of more than $1 \%$ occur at depths of $330 \mathrm{~m}$ below seafloor (mbsf) $(1.8 \%)$ and around 200 mbsf (up to $2.2 \%$ ), near the Valanginian/Hauterivian boundary and in the upper Barremian, respectively (Fig. 2).

The two Barremian samples from Site 640 have TOC values of $0.35 \%$ and $1.40 \%$ (Table 2).

At Site 641 , organic carbon values are distinctly higher than those at Site 638. In the interval between 250 and $150 \mathrm{mbsf}$ (Aptian to Albian), TOC contents of more than $1 \%$ are prevalent (Fig. 3). Furthermore, the sediments show cyclic changes in organic carbon, with minimum values of less than $0.5 \%$ and maximum values of up to about $5 \%$ (Fig. 3). In the Cenomanian(?) black shale section, TOC contents of more than $11 \%$ were recorded (Table 2; Shipboard Scientific Party, 1987c).

The organic carbon values compare well with those measured at nearby DSDP Sites 398 (Fig. 1) and 402 (northwest of Galicia Bank, not shown in Fig. 1). From an extensive survey of data in the literature, Stein et al. (1986) report maximum TOC values of $1 \%$ in the Hauterivian (Site 398), 2\% in the Barremian (Site 398), 3\% in the Aptian (Sites 398 and 402), 2\% and 3\% in the Albian (Sites 402 and 398, respectively), and $9 \%$ in the Cenomanian (Site 398).

According to records of carbonate content for Sites 638 (Fig. 2) and 641 (Fig. 3), the Valanginian to Albian section can be divided into three parts. The Valanginian is characterized by low carbonate values of less than $40 \%$ (Fig. 2). Within the Hauterivian to lower Aptian, the carbonate content increases to values distinctly higher than $40 \%$, reaching its maximum of more than $90 \%$ within the Barremian (Figs. 2 and 3). The upper Aptian to
Albian is characterized by an extremely low carbonate content of generally less than $10 \%$ (Fig. 3).

\section{Kerogen Type}

Rock-Eval pyrolysis and kerogen microscopy data were used to obtain information about the type of organic matter in the sediments. Our Rock-Eval results support those produced aboard JOIDES Resolution (Figs. 4 and 5; Shipboard Scientific Party, 1987a, 1987b, 1987c). Low hydrogen index values were recorded for the Valanginian/Hauterivian samples from Site 638 and the lower Barremian samples from Site 640, whereas the middle and upper Barremian samples from Site 638 are characterized by higher hydrogen indices of about 300 (Fig. 4 and Table 2). The hydrogen and oxygen index values indicate the dominance of kerogen type III in the Valanginian to lower Barremian section and the dominance of a mixture of kerogen types II and III in the middle/upper Barremian (Figs. 4 and 5). The Aptian/Albian hydrogen index values vary from less than 10 to about 200 (Site 641; Fig. 5 and Table 2). In the uppermost Cenomanian at Site 641 , maximum hydrogen index values reach to more than 500 , and the organic matter is of type II (Fig. 5).

The data derived from kerogen microscopy, as summarized in Table 3, corroborate the Rock-Eval results. Predominantly terrigenous macerals (i.e., vitrinites and terrestrial liptinites) accumulated in the Galicia margin sediments during the Early and middle Cretaceous and comprise between $50 \%$ and $95 \%$ of the total maceral content on a volume basis (Table 3 ). In general, samples with low hydrogen index values contain high amounts of terrestrial macerals (Tables 2 and 3). The main component is vitrinite, a major proportion of which is reworked, as shown in Table 3 and in the reflectance histograms of Figure 6. There are only two sediment samples with negligible amounts of reworked vitrinites. One of these is Sample 103-638B-35R-4, $75 \mathrm{~cm}$, an upper Valanginian to lower Hauterivian claystone from a turbidite sequence, which is characterized by the maximum vitrinite content within the sediment series investigated in this study. The other is Sample 103-641A-6X, CC (12 cm) from the Cenoma-

Table 2. Organic and inorganic carbon data and results of Rock-Eval pyrolysis of samples from Sites 638, 640, and 641 .

\begin{tabular}{|c|c|c|c|c|c|c|c|c|c|}
\hline Sample & $\begin{array}{c}\mathrm{CaCO}_{3} \\
(\%)\end{array}$ & $\begin{array}{l}\text { TOC } \\
(\%)\end{array}$ & S1 & $\mathrm{S} 2$ & S3 & $\begin{array}{l}\mathrm{T}_{\max } \\
\left({ }^{\circ} \mathrm{C}\right)\end{array}$ & $\begin{array}{l}\text { Productivity } \\
\text { index }\end{array}$ & $\begin{array}{l}\text { Hydrogen } \\
\text { index }\end{array}$ & $\begin{array}{c}\text { Oxygen } \\
\text { index }\end{array}$ \\
\hline $103-638 \mathrm{~B}-20 \mathrm{R}-3,35 \mathrm{~cm}$ & 56.7 & 1.51 & 0.29 & 3.97 & 2.16 & 424 & 0.07 & 263 & 143 \\
\hline $21 \mathrm{R}-1,23 \mathrm{~cm}$ & 90.0 & 0.09 & - & - & - & - & - & - & 一 \\
\hline $21 \mathrm{R}-3,113 \mathrm{~cm}$ & 44.6 & 2.24 & 0.12 & 6.04 & 3.15 & 424 & 0.02 & 270 & 141 \\
\hline $21 \mathrm{R}-4,57 \mathrm{~cm}$ & 89.0 & 0.12 & - & - & - & - & - & - & - \\
\hline $24 \mathrm{R}-3,2 \mathrm{~cm}$ & 39.5 & 0.91 & 0.17 & 1.01 & 2.60 & 425 & 0.14 & 111 & 286 \\
\hline $35 \mathrm{R}-4,75 \mathrm{~cm}$ & 5.7 & 1.82 & 0.10 & 1.11 & 1.69 & 421 & 0.08 & 61 & 93 \\
\hline $41 \mathrm{R}-1,125 \mathrm{~cm}$ & 13.4 & 0.92 & 0.08 & 0.84 & 1.46 & 427 & 0.09 & 91 & 159 \\
\hline $41 \mathrm{R}-2,32 \mathrm{~cm}$ & 32.5 & 0.11 & - & - & - & - & - & - & - \\
\hline $103-640 \mathrm{~A}-4 \mathrm{R}-1,9 \mathrm{~cm}$ & 35.9 & 1.40 & 0.15 & 1.48 & 3.15 & 425 & 0.09 & 106 & 225 \\
\hline $4 \mathrm{R}-1,26 \mathrm{~cm}$ & 74.6 & 0.35 & 0.04 & 0.24 & 1.26 & - & 0.14 & 69 & 360 \\
\hline $103-641 \mathrm{~A}-5 \mathrm{X}-3,9 \mathrm{~cm}$ & 0.7 & 0.05 & - & - & - & - & - & - & - \\
\hline $6 \mathrm{X}, \mathrm{CC}(12 \mathrm{~cm})$ & 3.8 & 11.35 & 0.69 & 36.37 & - & 407 & 0.02 & 321 & - \\
\hline $7 \mathrm{X}-1,49 \mathrm{~cm}$ & 35.2 & 0.23 & - & - & - & - & - & - & - \\
\hline $7 X-3,14 \mathrm{~cm}$ & 42.9 & 0.68 & 0.42 & 0.79 & 2.97 & - & 0.35 & 116 & 437 \\
\hline $103-641 \mathrm{C}-1 \mathrm{R}-1,145 \mathrm{~cm}$ & 26.2 & 0.20 & - & - & - & - & - & 一 & - \\
\hline $1 \mathrm{R}-2,6 \mathrm{~cm}$ & 11.5 & 1.32 & 0.49 & 1.32 & 2.27 & - & 0.27 & 100 & 172 \\
\hline $1 \mathrm{R}-2,20 \mathrm{~cm}$ & 20.7 & 1.64 & 0.50 & 1.62 & 2.52 & 416 & 0.24 & 99 & 154 \\
\hline $2 \mathrm{R}-5,147 \mathrm{~cm}$ & 0.7 & 0.20 & - & - & - & - & - & - & - \\
\hline $2 \mathrm{R}-6,43 \mathrm{~cm}$ & 0.6 & 0.60 & 0.65 & 0.72 & 0.37 & - & 0.47 & 120 & 62 \\
\hline $2 \mathrm{R}-6,61 \mathrm{~cm}$ & 0.7 & 1.32 & 1.06 & 2.51 & 0.58 & - & 0.30 & 190 & 44 \\
\hline $3 \mathrm{R}-6,85 \mathrm{~cm}$ & 0.7 & 2.62 & 1.02 & 3.15 & 1.17 & - & 0.24 & 120 & 45 \\
\hline $4 \mathrm{R}-3,105 \mathrm{~cm}$ & 1.0 & 1.56 & 0.79 & 0.70 & 0.89 & - & 0.53 & 45 & 57 \\
\hline $4 \mathrm{R}-5,63 \mathrm{~cm}$ & 0.8 & 0.58 & 0.80 & 0.94 & 0.48 & - & 0.46 & 162 & 83 \\
\hline $4 \mathrm{R}-5,75 \mathrm{~cm}$ & 0.8 & 1.54 & 0.80 & 1.52 & 0.69 & - & 0.34 & 99 & 45 \\
\hline $8 \mathrm{R}-2,126 \mathrm{~cm}$ & 1.1 & 1.48 & 1.03 & 2.90 & 10.07 & - & 0.26 & 196 & 5 \\
\hline
\end{tabular}

Note: $-=$ not determined. 

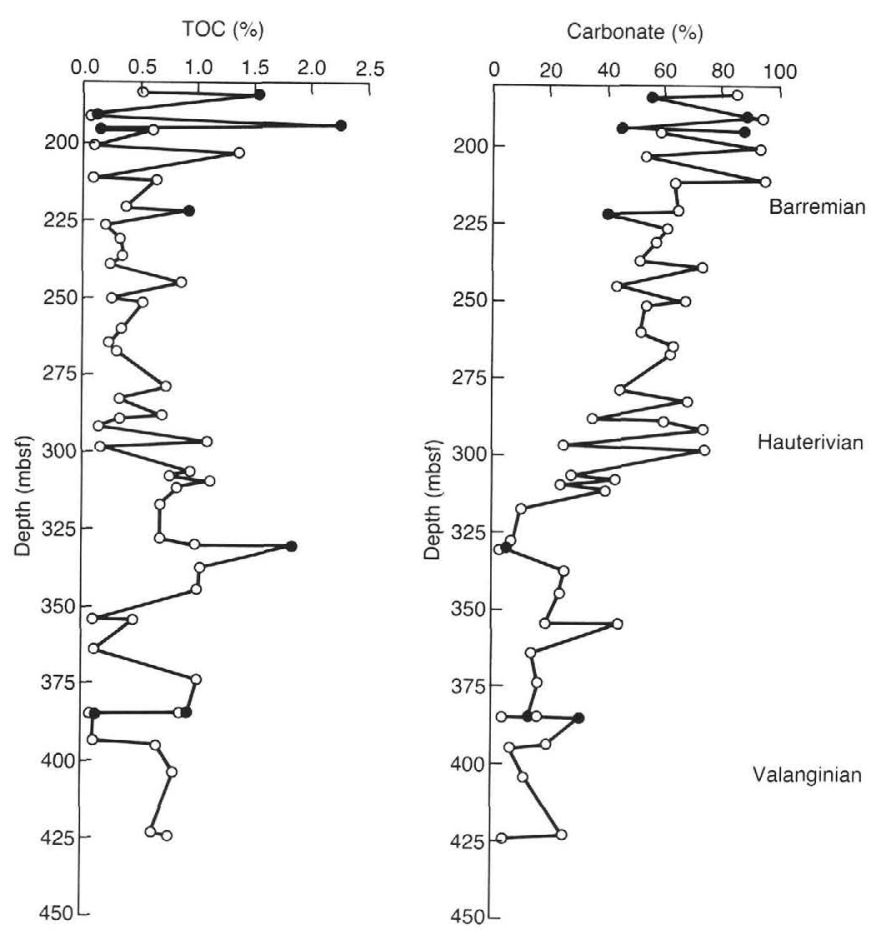

Figure 2. Organic and inorganic carbon data of Site 638 sediments. Open symbols are shipboard data (Shipboard Scientific Party, 1987a), solid symbols are data from this study.

nian/Turonian(?) black shale; this sample has a very low content of vitrinite but contains predominantly unstructured kerogen (bituminite; Table 3) presumably of marine origin, as indicated by the presence of recognizable algal remains.

Maturity of Organic Matter

The reflectance values of primary vitrinite are very low and vary between 0.27 and 0.38 (Table 3 ), indicating the immaturity of the organic matter. This agrees well with the low temperatures of maximum pyrolysis yield $\left(\mathrm{T}_{\max }\right)$, which range from $407^{\circ}$ to $427^{\circ} \mathrm{C}$ (Table 2). The occurrence of secondary vitrinites characterized by reflectance values of up to $1 \%$ (Fig. 6) implies the presence of redeposited and more mature material.

\section{Extractable Hydrocarbons}

In accordance with the low thermal maturity of the organic matter in the Galicia margin sediments, all extract yields were below $10 \mathrm{mg} / \mathrm{g}$ TOC, and, with few exceptions, the nonaromatic plus aromatic hydrocarbon fractions represent less than $20 \%$ of the total extracts. Capillary gas chromatograms of the nonaromatic hydrocarbon fractions of selected samples are shown in Figures 7 and 8. Compounds identified on the basis of their mass spectra and relative retention times are listed in Table 4.

The two Barremian and the Valanginian-Hauterivian sediment samples show multimodal $n$-alkane distributions (Fig. 7). Long-chain $n$-alkanes of higher plant wax origin with a maximum at $n-\mathrm{C}_{29}$ or $n-\mathrm{C}_{31}$ are particularly abundant in Sample 103638B-35R-4, $75 \mathrm{~cm}$ (Fig. 7C), important in Sample 103-638B21R-3, $113 \mathrm{~cm}$ (Fig. 7B), but minor in Sample 103-638B-20R-3, $35 \mathrm{~cm}$ (Fig. 7A). This is consistent with an increase in the relative importance of marine organic particles in this sample series (Table 3 ). The second $n$-alkane maximum clearly recognizable in all three samples is at $n-\mathrm{C}_{21}$ to $n-\mathrm{C}_{23}$ and probably arises from bacterial action on the deposited organic matter (Simoneit et al., 1979, and references therein). The significance of the third maximum at $n-C_{17}$ (or $n-C_{19}$ ) is less obvious. It may be due partly to the presence of recycled, more mature organic matter (which also will contribute to the longer-chain $n$-alkanes without odd-over-even carbon number predominance), as in Sample 103-638B-20R-3, $35 \mathrm{~cm}$ (Fig. 7A; cf. Fig. 6); to algal remains, as
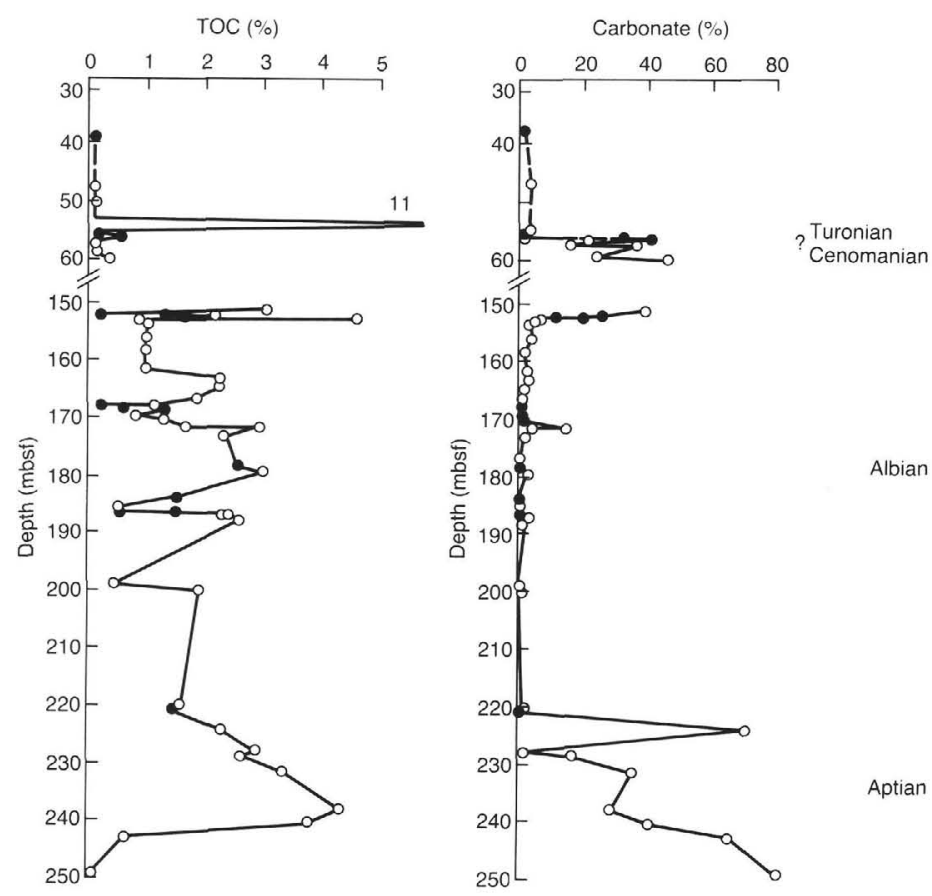

Figure 3. Organic and inorganic carbon data of Site 641 sediments. Open symbols are shipboard data (Shipboard Scientific Party, 1987c), solid symbols are data from this study. 


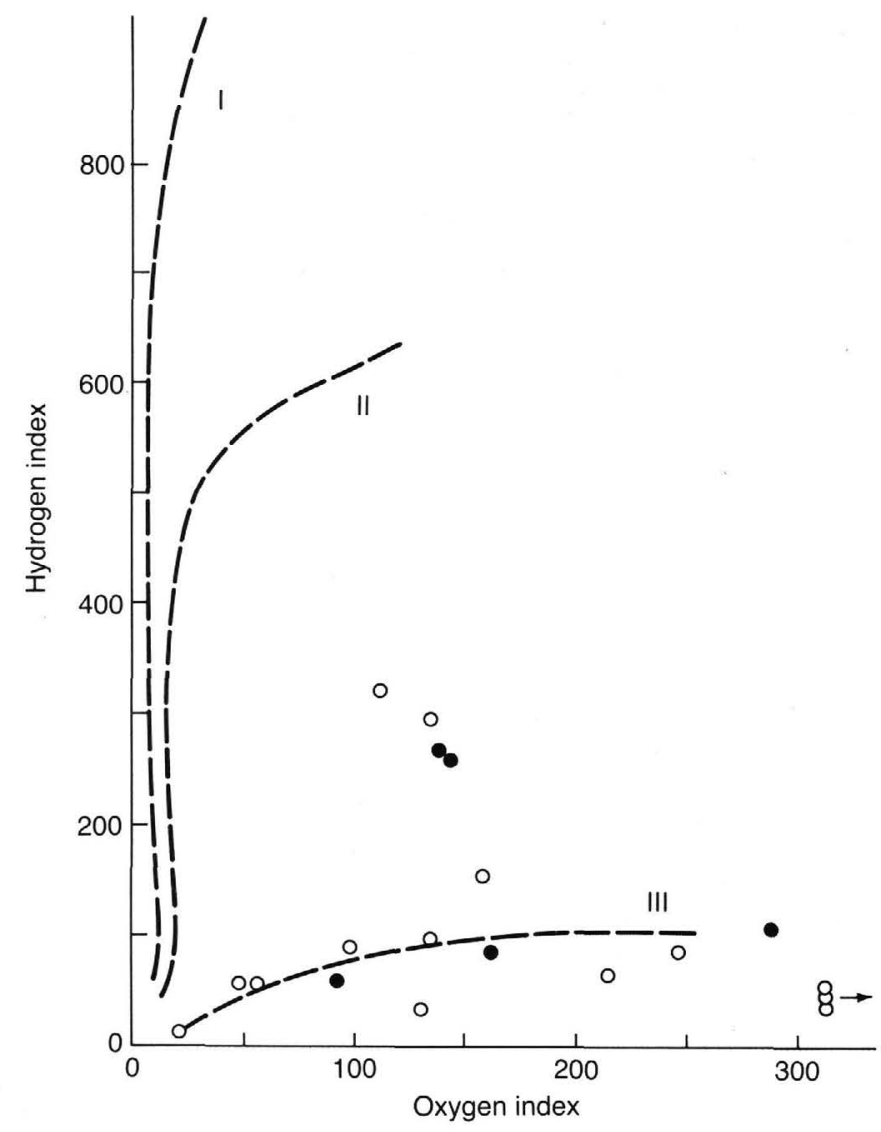

Figure 4. Results of Rock-Eval pyrolysis displayed on hydrogen index vs. oxygen index diagram (Espitalié et al., 1977) for sediment samples from Site 638. Open circles are shipboard data (Shipboard Scientific Party, 1987a), solid circles are data from this study.

possible in Sample 103-638B-21R-3, $113 \mathrm{~cm}$, which contains mixed marine and terrigenous organic matter; or, as in the case of Valanginian-Hauterivian sediment that contains neither major amounts of marine organic matter nor recycled vitrinites, to the microbial degradation of terrigenous organic material. A similar variation of $n$-alkane patterns has been observed by $\mathrm{Si}$ moneit and Mazurek (1979) in Albian and Aptian deep-sea sediments from Site 398.

The terrigenous nature of the organic matter in the Valanginian-Hauterivian sample (Fig. 7C) is further demonstrated by the occurrence of a complex mixture of cyclic diterpenoid hydrocarbons, which have precursors that are particularly common in higher plants (Simoneit, 1986a). However, none of these hydrocarbons could be investigated with their full chemical structures. In addition to those marked in Figure 7C, a variety of minor cyclic diterpenoid components are present. These compounds were not observed in any of the other Leg 103 samples investigated in this study.

A record of microbial activity in the two Barremian samples is derived from the abundance of hopanoid hydrocarbons (Figs. $7 \mathrm{~A}$ and $7 \mathrm{~B}$ ), of which $17 \beta(\mathrm{H})$-homohopane is the most important single compound in the nonaromatic hydrocarbon fractions of these sediments. Fernenes also present in high relative concentrations have been attributed to the same source (Brassell et al., 1981). Hopanoid hydrocarbons, particularly those with more than 30 carbon atoms, are of remarkably low relative abundance in the upper Valanginian-Hauterivian sample (Fig. 7C), although the fernenes do not show the same decrease. On

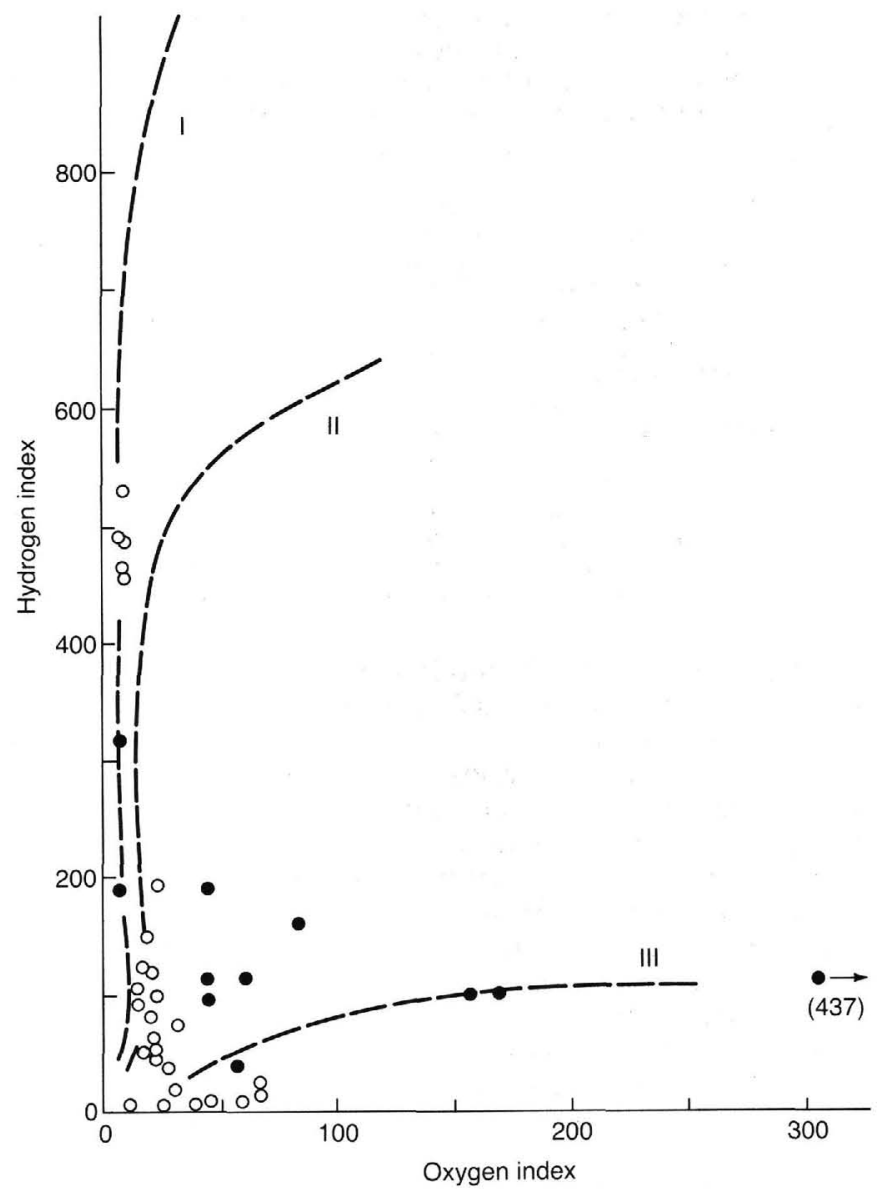

Figure 5. Results of Rock-Eval pyrolysis displayed on hydrogen index vs. oxygen index diagram (Espitalié et al., 1977) for sediment samples from Site 641. Open circles are shipboard data (Shipboard Scientific Party, 1987c), solid circles are data from this study.

the other hand, $\mathrm{C}_{25}$ and $\mathrm{C}_{30}$ acyclic isoprenoid hydrocarbons present only in this sample may be indicators of methanogenic bacterial activity in the sediment (Brassell et al., 1981), suggesting that the microbial ecosystem in the Valanginian-Hauterivian sediment was different from that in the Barremian at the time of deposition.

Steranes and sterenes are minor constituents in all three Hole $638 \mathrm{~B}$ samples. Slightly higher concentrations of the $\mathrm{C}_{27}$ steroids in the Barremian samples are consistent with their macroscopically observed higher relative proportions of marine organic matter. The low overall concentrations of the labile steroids indicate that accumulation of organic matter was controlled mainly by the sedimentation rate rather than an anoxic water body, thus favoring the preservation of terrigenous organic matter.

The $n$-alkane distributions of the Albian and Aptian samples do not differ very much from each other (Figs. 8B through 8E). Long-chain wax alkanes dominate, and the maximum is at $n$ $\mathrm{C}_{31}$ in each case. Less prominent $n$-alkane maxima are due to bacterial contribution or the presence of reworked organic matter, as described previously. As in the Barremian sediments, the relative concentration of steroid hydrocarbons is low. The major molecular fossils of microbial origin in the nonaromatic hydrocarbon fractions are $17 \beta(\mathrm{H})$-hopanes, hopenes, and fernenes; the fernenes have considerably lower relative abundances than in the Barremian samples. The most abundant component in the nonaromatic hydrocarbon fraction of the shallowest Albian 
Table 3. Maceral percentages and mean vitrinite-reflectance values of samples from Sites 638 and 641 . Three types of vitrinite are distinguished. Usually bright vitrinite is called "reworked vitrinite" or "semiinertinite" in the literature (e.g., Stach et al., 1982). Terrestrial liptinites are sporinites and-rarely-cutinites and resinites. Particles that could not be identified as terrestrial liptinites or alginites are combined under the term liptodetrinite. Vitrinites and inertinites that are less than $30 \mu \mathrm{m}$ in diameter are called "small particles."

\begin{tabular}{|c|c|c|c|c|c|c|c|c|c|c|}
\hline Sample & $\begin{array}{c}\text { Dark } \\
\text { vitrinite }\end{array}$ & Vitrinite & $\begin{array}{c}\text { Light } \\
\text { vitrinite }\end{array}$ & Inertinite & $\begin{array}{c}\text { Terrestrial } \\
\text { liptinite }\end{array}$ & Bituminite & $\begin{array}{l}\text { Marine } \\
\text { liptinite }\end{array}$ & $\begin{array}{l}\text { Lipto- } \\
\text { detrinite }\end{array}$ & $\begin{array}{c}\text { Small } \\
\text { particles } \\
(<30 \mu \mathrm{m})\end{array}$ & $\begin{array}{c}\text { Vitrinite } \\
\text { reflectance } \\
\text { values }(\%)\end{array}$ \\
\hline 103-638B-20R-3, $35 \mathrm{~cm}$ & 3 & 7 & 25 & 7 & 10 & 0 & 17 & 30 & 88 & 0.29 \\
\hline $21 \mathrm{R}-3,113 \mathrm{~cm}$ & 4 & 9 & 23 & 6 & 23 & 0 & 14 & 21 & 95 & 0.33 \\
\hline $35 \mathrm{R}-4,75 \mathrm{~cm}$ & 10 & 78 & 2 & 2 & 5 & 0 & 2 & 3 & 64 & 0.33 \\
\hline $103-640 \mathrm{~A}-4 \mathrm{R}-1,9 \mathrm{~cm}$ & - & - & - & - & - & - & - & - & - & 0.27 \\
\hline $103-641 \mathrm{~A}-6 \mathrm{X}, \mathrm{CC}(12 \mathrm{~cm})$ & 0 & 3 & 0 & 6 & 0 & 48 & 15 & 28 & 100 & - \\
\hline $103-641 \mathrm{C}-1 \mathrm{R}-2,6 \mathrm{~cm}$ & - & - & - & - & - & - & - & - & - & 0.33 \\
\hline $1 \mathrm{R}-2,20 \mathrm{~cm}$ & 0 & 9 & 31 & 7 & 23 & 0 & 6 & 23 & 100 & - \\
\hline $3 \mathrm{R}-6,85 \mathrm{~cm}$ & 1 & 10 & 35 & 6 & 13 & 0 & 12 & 24 & 100 & 0.31 \\
\hline $4 \mathrm{R}-3,105 \mathrm{~cm}$ & 1 & 3 & 57 & 7 & 11 & 0 & 7 & 14 & 98 & 0.38 \\
\hline $4 \mathrm{R}-5,75 \mathrm{~cm}$ & 0 & 4 & 33 & 6 & 11 & 0 & 17 & 30 & 100 & 0.32 \\
\hline $8 \mathrm{R}-2,126 \mathrm{~cm}$ & 0 & 18 & 30 & 5 & 19 & 0 & 8 & 20 & 100 & 0.29 \\
\hline
\end{tabular}

sample (103-641C-1R-2, $20 \mathrm{~cm})$ is an unknown compound with a molecular weight of 386 , as determined by mass spectrometry (Fig. 8B and Table 4).

A very broad $n$-alkane distribution from $n-\mathrm{C}_{12}$ to $n-\mathrm{C}_{36}$ with a slight odd-over-even carbon number predominance over most of this range and a weak maximum at $n-\mathrm{C}_{27}$ characterizes the nonaromatic hydrocarbon fraction of the Cenomanian/Turonian(?) black shale sample (103-641A-6X, CC (12 cm); Fig. 8A). Such a pattern is not common, but the microscopy results suggest that it is related to the bacterial imprint on the original (marine) organic matter deposited. Recognizable cyclic hydrocarbons, of which hop-17(21)-enes and $17 \beta(\mathrm{H})$-hopanes are the most abundant representatives, account for only a relatively small proportion of the nonaromatic hydrocarbon fraction. There is, however, a major unresolved "hump" indicating the presence of a complex mixture of branched and/or cyclic hydrocarbons, although it may have resulted from some secondary alteration when the black shale sample was kept at ambient temperature for several days before analysis. It is possible that the same secondary process is also responsible for the relatively low hydrogen index value we measured for this sample in our laboratory, in comparison to measurements obtained aboard ship from the black shale (Fig. 5).

In the aromatic hydrocarbon fractions of samples from Sites 638 and 641 , only the steroidal compounds were examined in detail. Figures 9 and 10 show mass fragmentograms of the molecular ions of $\mathrm{C}_{27}$ to $\mathrm{C}_{29}$ triunsaturated and tetraunsaturated steroid hydrocarbons, which, in part, are true aromatic compounds and in some cases appear to contain several isolated or conjugated double bonds in the steroid ring system and/or side chain. Because of their liquid chromatographic behavior, polyolefinic steroids occur together with the aromatic steroid hydrocarbons in the same fraction. Based on mass spectrometric key fragments, a total of seven series of polyunsaturated steroid hydrocarbons were detected, though only for some of them could the double bonds be located and structures assigned (Table 5).

In Sample 103-638B-21R-1, $113 \mathrm{~cm}$, (Barremian) steroid hydrocarbons are by far the most dominant components in the aromatic hydrocarbon fraction. Within the steroid group, the $\mathrm{C}_{29}$ monoaromatic series have the highest relative abundance, followed by the $C_{27}$ monoaromatics and the $C_{28}$ tetraenes, some of which may be monoaromatic with an additional double bond in the side chain (Fig. 9B). The upper Barremian sediment has a conspicuously low relative concentration of the $\mathrm{C}_{29}$ monoaromatic steroids, showing instead a dominance of $\mathrm{C}_{28}$ and $\mathrm{C}_{29}$ tetraenes (Fig. 9A). In contrast, the aromatic $\mathrm{C}_{29}$ steroids are essentially the only compounds of this type in the upper Valangin- ian-lower Hauterivian sediment (Fig. 9C), which has been shown to contain abundant terrigenous organic matter. In these latter two sediment samples, steroid hydrocarbons have an intermediate concentration in the total aromatic hydrocarbon fractions.

The Albian and Aptian sediments show fairly uniform distributions of polyunsaturated steroid hydrocarbons (Figs. 10B through 10E). Within the aromatic hydrocarbon fractions their concentrations are moderate to low, in accordance with a minor marine contribution under oxic depositional conditions. The most abundant single steroid component in each case is the Aring monoaromatic $\mathrm{C}_{29}$ steroid hydrocarbon, followed by the corresponding $\mathrm{C}_{27}$ homolog and the series of $\mathrm{C}_{28}$ tetraenes. In the Cenomanian black shale, the polyunsaturated steroid hydrocarbon pattern is highly complex (Fig. 10A) and in addition to those marked and listed in Table 5, may contain many more compounds of this type. Nonsteroid components also contribute to the molecular ion fragmentograms; however, an unresolved complex mixture is present in this fraction, giving rise to a major "hump," as is the case in the saturated hydrocarbon fraction.

\section{DISCUSSION}

\section{Organofacies and Depositional Environment}

Except for the Cenomanian/Turonian section at Site 641, terrigenous organic carbon dominated the organic matter deposited on the Galicia continental margin throughout the Early and middle Cretaceous. This agrees well with data on the Cretaceous recorded at nearby DSDP Site 398 (Cornford, 1979; Simoneit and Mazurek, 1979) and at northeastern Atlantic DSDP Sites 400 and 402 (de Graciansky et al., 1979). Thus, the new data from ODP Leg 103 strengthen the general ideas about the depositional history of the organic matter of Cretaceous black shales in the North Atlantic: with the exception of the Cenomanian/Turonian section, terrigenous organic matter is dominant in the western North Atlantic and the northern northeast Atlantic, whereas marine organic matter is dominant in the upwelling areas off northwest Africa (e.g., Tissot et al., 1980; Arthur et al., 1984; Rullkötter and Mukhopadhyay, 1986; Stein et al., 1986). During the Cenomanian/Turonian event, the preservation of marine organic carbon was significant in the entire North Atlantic.

In the late Valanginian and early Hauterivian, the oldest time interval discussed in this paper, accumulation rates of (mainly terrigenous) organic matter were relatively high (about $0.05 \mathrm{gC} / \mathrm{cm}^{2} / 1000 \mathrm{yr}$; Fig. 11). This increased supply of terrigenous organic material may have resulted from a dominantly humid climate in southwest Europe (Hallam, 1984). Furthermore, 

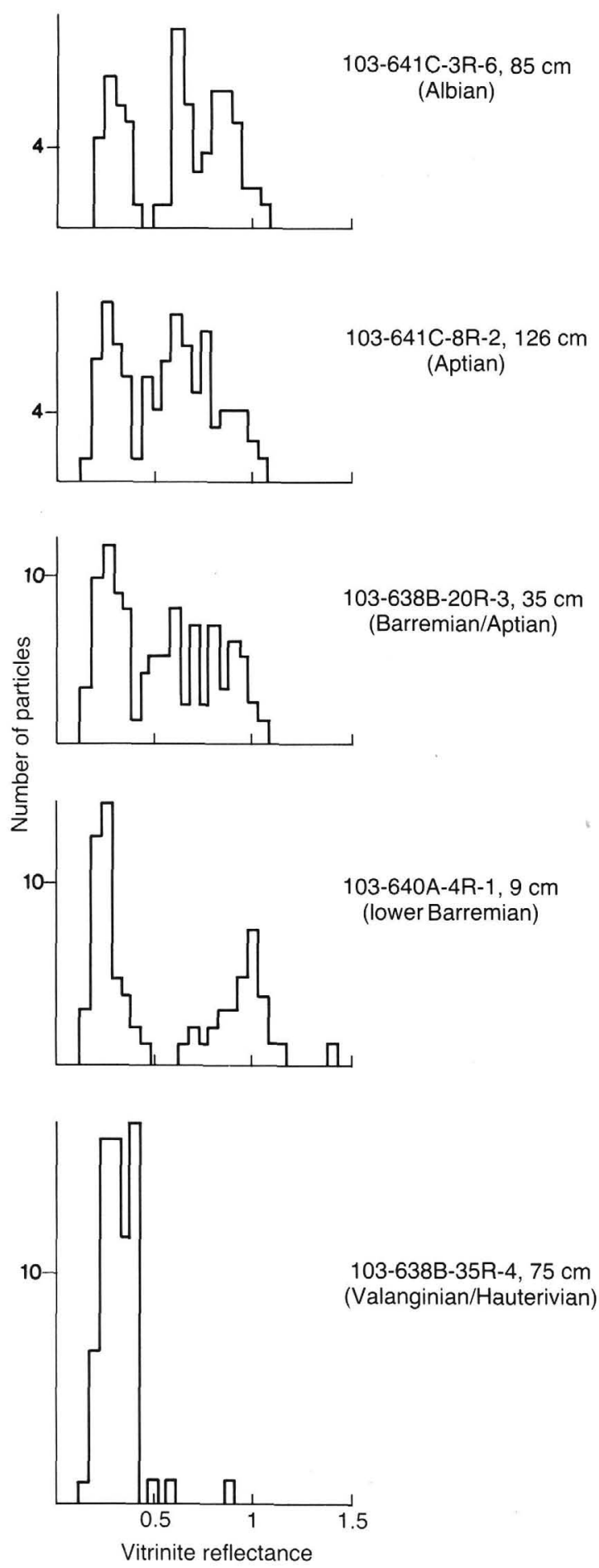

Figure 6. Vitrinite reflectance histograms of selected samples from Sites 638,640 , and 641 .

sea level was probably lowered (Vail et al., 1980), favoring the transport of terrigenous material across the shelf edge down to the continental rise. Turbidity currents were the main downslope transport mechanism during that time (Shipboard Scientific Party, 1987a). For example, the maximum TOC value at a depth of about 325 mbsf at Site 638 (Fig. 2) occurs within a turbidite horizon. Rapid burial by turbidites resulted in better preservation of distinctly coarser organic particles in the sediment (Sample 103-638B-35R-4, 75 cm; Table 3; cf. Rullkötter et al., 1983;
Arthur et al., 1984), and coarse-grained woody material is also common (Shipboard Scientific Party, 1987a). The amount of marine organic carbon in the rapidly buried Sample 103-638B$35 \mathrm{R}-4,75 \mathrm{~cm}$, is negligible (Tables 3 and 6), which is explained by a low oceanic productivity (about $25 \mathrm{gC} / \mathrm{m}^{2} / \mathrm{yr}$; Table 6 ) and oxic seawater conditions at the Galicia continental margin during the Valanginian-Hauterivian.

In the overlying middle Hauterivian and upper Barremian section (the upper Hauterivian/lower Barremian was unfortunately not recovered because of a stratigraphic gap; Shipboard Scientific Party, 1987a), the accumulation rate of organic carbon had decreased to less than $0.02 \mathrm{gC} / \mathrm{cm}^{2} / 1000 \mathrm{yr}$ (Fig. 11). This is interpreted as the result of a reduced supply of material from the continent. Because the climate on the nearby continent was still humid (Hallam, 1984), this decrease in the supply of terrigenous matter may have been caused by a higher sea level (Vail et al., 1980), resulting in an inundated shelf area that acted as a sediment trap for terrigenous (i.e., fluvial) muds.

Although the organic matter is dominantly terrigenous within the Barremian, somewhat higher amounts of marine particles were recorded. According to the kerogen microscopy data, up to $20 \%$ of the TOC may have been of marine origin (Table 6). Based on these data, an increased paleoproductivity of about $140 \mathrm{gC} / \mathrm{m}^{2} / \mathrm{yr}$ was estimated (Table 6 ), possibly caused by an increased fluvial nutrient supply (cf. Stein, 1985). As shown in Figure 12, the Barremian sediments were deposited in an oxic deep-water environment.

In the earliest Aptian, the supply of terrigenous organic matter reached a distinct and short-lived maximum of up to 0.12 $\mathrm{gC} / \mathrm{cm}^{2} / 1000$ yr (Fig. 11). This event was almost contemporaneous with a short-term regression recorded by Vail et al. (1980), which could explain the increased transport of terrigenous matter across the shelf edge to the location of Site 641 .

During the Aptian and Albian, low accumulation rates of less than $0.03 \mathrm{gC} / \mathrm{cm}^{2} / 1000 \mathrm{yr}$ for (mainly terrigenous) organic matter were prevalent (Fig. 11). This reduced supply of terrigenous matter was due to a relatively high sea-level stand (Vail et al., 1980). The cyclic variations in organic carbon contents (Figs. 3 and 11) may have been caused by variations of climate (cf. Fischer and Arthur, 1977; Arthur et al., 1984), influencing the supply of terrigenous matter (i.e., organic and siliciclastic material, as well as dissolved nutrients). The latter may have triggered the variations in surface-water productivity estimated from the marine organic carbon data (Table 6). However, changes in upwelling intensity off Portugal that parallel climatic changes (cf., Diester-Haass, 1983; Stein, 1985) could have also affected paleoproductivity.

A drastic change in depositional environment must have occurred in the latest Cenomanian; large amounts of marine organic matter are preserved in sediments of this age. Probably $90 \%$ of the TOC is marine (i.e., the sediments contain more than $10 \%$ marine organic carbon; Table 6). These extremely high values require unusual environmental conditions that could have resulted in either extremely high productivity (such as recorded in coastal upwelling areas) or better preservation of organic matter owing to anoxic deep-water conditions (such as recorded in the modern Black Sea) (e.g., Schlanger and Jenkyns, 1976; Demaison and Moore, 1980; Arthur et al., 1984). Areas of high productivity are generally characterized by high sedimentation rates (Fig. 12; Stein, 1986a). However, extremely low sedimentation rates of about $0.2 \mathrm{~cm} / 1000 \mathrm{yr}$ were likely at Site 641 during the Cenomanian (Shipboard Scientific Party, 1987c; Table 6). The comparison of organic carbon data and sedimentation rates favors anoxic deep-water conditions as the main cause for the preservation of high amounts of marine organic matter (Fig. 12). Higher paleoproductivity was rather unlikely (Table 6). This agrees well with Cenomanian/Turonian data de- 
Table 4. Major biological marker constituents in the nonaromatic hydrocarbon fractions of sediments from ODP Sites 638 and 641 (cf. Figs. 7 and 8). See Appendix for compound structures.

\begin{tabular}{|c|c|c|c|c|}
\hline Code & Compounds & Structure & $\begin{array}{l}\text { Molecular } \\
\text { ion }\end{array}$ & Key fragments ${ }^{\mathrm{a}}$ \\
\hline a & Norpristane & $\mathrm{I}(\mathrm{R}=\mathrm{H})$ & & \\
\hline b & $\mathrm{C}_{19}$ diterpenoid & & 260 & $245,191(\mathrm{BP})$ \\
\hline c & Pristene & & 266 & \\
\hline $\mathrm{d}$ & Pristane & $\mathrm{I}\left(\mathrm{R}=\mathrm{CH}_{3}\right)$ & & \\
\hline $\mathrm{e}$ & $\mathrm{C}_{19}$ diterpenoid & & 260 & 245,205 (BP) \\
\hline f & $\mathrm{C}_{18}$ diterpenoid & & 250 & $235,128(\mathrm{BP})$ \\
\hline $\mathrm{g}$ & $\mathrm{C}_{19}$ diterpenoid & & 264 & 249,123 (BP) \\
\hline $\mathrm{h}$ & $\mathrm{C}_{18}$ diterpenoid & & 248 & $191,163,135(\mathrm{BP})$ \\
\hline $\mathrm{i}$ & Phytane & $\mathrm{I}\left(\mathrm{R}=\mathrm{C}_{2} \mathrm{H}_{5}\right)$ & & \\
\hline $\mathrm{j}$ & $\mathrm{C}_{20}$ diterpenoid & & 278 & $163,123(\mathrm{BP})$ \\
\hline $\mathrm{k}$ & $\mathrm{C}_{19}^{20}$ diterpenoid & & 262 & 233(BP) \\
\hline 1 & $\mathrm{C}_{20}$ diterpenoid & & 274 & $259,154,57(\mathrm{BP})$ \\
\hline $\mathrm{m}$ & $\mathrm{C}_{20}$ diterpenoid & & 278 & $263,191,149$ (BP) \\
\hline $\mathrm{n}$ & Unknown & & 268 & $253,57(\mathrm{BP})$ \\
\hline 0 & 2,6,10,14,18-pentamethyleicosane & II & & \\
\hline $\mathrm{p}$ & Unknown & & $390 ?$ & 111(BP) \\
\hline q & $2,6,10,14,18,22$-hexamethyltetracosane & III & & \\
\hline $\mathrm{r}$ & $\begin{array}{l}2,6,10,15,19,23 \text {-hexamethyltetracosane } \\
\text { (squalane) }\end{array}$ & IV & & \\
\hline $\mathrm{s}$ & Unknown & & 386 & 357 \\
\hline $\mathrm{t}$ & 24-ethyldiacholest-13(17)-ene & $\mathrm{V}$ & & \\
\hline u & 22,29,30-trisnorneohop-13(18)-ene & $\mathrm{VI}(\mathrm{R}=\mathrm{H})$ & & \\
\hline $\mathrm{v}$ & Cholest-4-ene & $\operatorname{VII}(\mathrm{R}=\mathrm{H})$ & & \\
\hline w & Cholest-5-ene & $\operatorname{VIII}(\mathrm{R}=\mathrm{H})$ & & \\
\hline $\mathrm{x}$ & $5 \alpha(\mathrm{H})$-cholestane & $\mathrm{IX}(\mathrm{R}=\mathrm{H})$ & & \\
\hline $\mathrm{y}$ & Unknown $\mathrm{C}_{30}$ triterpane & & 412 & 299 \\
\hline $\mathrm{z}$ & Unknown & & 414 & 149(BP) \\
\hline$a^{\prime}$ & $22,29,30$-trisnor-17 $\alpha(\mathrm{H})$-hopane & $X(R=H)$ & & \\
\hline $\mathrm{b}^{\prime}$ & $22,29,30$-trisnor-17 $\beta(\mathrm{H})$-hopane & $\mathrm{XI}(\mathrm{R}=\mathrm{H})$ & & \\
\hline $\mathrm{c}^{\prime}$ & 28,30 -bisnor- $17 \alpha(\mathrm{H}), 18 \alpha(\mathrm{H})$-hopane & XII & & \\
\hline$d^{\prime}$ & 24-ethylcholest-4-ene & $\operatorname{VII}\left(\mathrm{R}=\mathrm{C}_{2} \mathrm{H}_{5}\right)$ & & \\
\hline $\mathrm{e}^{\prime}$ & 30-nor-17 $\alpha(\mathrm{H})$-hopane & $\mathrm{X}\left(\mathrm{R}=\mathrm{C}_{2} \mathrm{H}_{5}\right)$ & (BP) & \\
\hline $\mathrm{f}^{\prime}$ & Unknown & & 386 & $371(\mathrm{BP}), 365,357,177,133$ \\
\hline $\mathrm{g}^{\prime}$ & 24-ethylcholest-5-ene & $\operatorname{VIII}\left(\mathrm{R}=\mathrm{C}_{2} \mathrm{H}_{5}\right)$ & & \\
\hline $\mathrm{h}^{\prime}$ & 24-ethyl- $5 \alpha(\mathrm{H})$-cholestane & $\mathrm{IX}\left(\mathrm{R}=\mathrm{C}_{2} \mathrm{H}_{5}\right)$ & & \\
\hline $\mathrm{i}^{\prime}$ & 30-norhop-17(21)-ene & $X I I I(R=H)$ & & \\
\hline $\mathrm{j}^{\prime}$ & Diunsaturated triterpane & & 408 & 393,187(BP) \\
\hline $\mathrm{k}^{\prime}$ & Hop-17(21)-ene & $\mathrm{XIII}\left(\mathrm{R}=\mathrm{CH}_{3}\right)$ & & \\
\hline $1^{\prime}$ & 30-normoretane & $X I V(R=H)$ & & \\
\hline $\mathrm{m}^{\prime}$ & $17 \alpha(\mathrm{H})$-hopane & $\mathrm{X}\left(\mathrm{R}=\mathrm{CH}\left(\mathrm{CH}_{3}\right)_{2}\right)$ & & \\
\hline $\mathrm{n}^{\prime}$ & Fern-8-ene & $\mathrm{XV}$ & & \\
\hline $0^{\prime}$ & Neohop-13(18)-ene & $\mathrm{VI}\left(\mathrm{R}=\mathrm{CH}\left(\mathrm{CH}_{3}\right)_{2}\right)$ & & \\
\hline $\mathrm{p}^{\prime}$ & 30-nor-18 $\beta(\mathrm{H})$-hopane & $\mathrm{XI}\left(\mathrm{R}=\mathrm{C}_{2} \mathrm{H}_{5}\right)$ & & \\
\hline$q^{\prime}$ & Fern-9(11)-ene & XVI & & \\
\hline $\mathrm{r}^{\prime}$ & Homohop-17(21)-ene (22S + R) & $\mathrm{XI}\left(\mathrm{R}=\mathrm{C}_{2} \mathrm{H}_{5}\right)$ & & \\
\hline $\mathrm{s}^{\prime}$ & Fern-7-ene & XVII & & \\
\hline $\mathrm{t}^{\prime}$ & Unknown & & 454 & 189(BP) \\
\hline $\mathrm{u}^{\prime}$ & $17 \alpha(\mathrm{H})$-homohopane $(22 \mathrm{~S}+\mathrm{R})$ & $\mathrm{X}\left(\mathrm{R}=\mathrm{CH}\left(\mathrm{CH}_{3}\right) \mathrm{C}_{2} \mathrm{H}_{5}\right)$ & & \\
\hline$v^{\prime}$ & Hopane & $\mathrm{XI}\left(\mathrm{R}=\mathrm{CH}\left(\mathrm{CH}_{3}\right)_{2}\right)$ & & \\
\hline $\mathrm{w}^{\prime}$ & Homomoretane & $\mathrm{XIV}\left(\mathrm{R}=\mathrm{C}_{2} \mathrm{H}_{5}\right)$ & & \\
\hline $\mathrm{x}^{\prime}$ & $17 \alpha(\mathrm{H})$-bishomohopane $(22 \mathrm{~S}+\mathrm{R})$ & $\mathrm{X}\left(\mathrm{R}=\mathrm{CH}\left(\mathrm{CH}_{3}\right) \mathrm{C}_{3} \mathrm{H}\right)$ & & \\
\hline$y^{\prime}$ & $\mathrm{C}_{31}$ triterpane & & 424 & $369,203(\mathrm{BP}), 191$ \\
\hline$z^{\prime}$ & Bishomomoretane & $\operatorname{XIV}\left(\mathrm{R}=\mathrm{C}_{3} \mathrm{H}_{7}\right)$ & & \\
\hline $\mathrm{a}^{\prime \prime}$ & Unknown & & 482 & 217(BP) \\
\hline$b^{\prime \prime}$ & Homohopane & $\mathrm{XI}\left(\mathrm{R}=\mathrm{CH}\left(\mathrm{CH}_{3}\right) \mathrm{C}_{2} \mathrm{H}_{5}\right)$ & & \\
\hline$c^{\prime \prime}$ & Bishomohopane & $\mathrm{XI}\left(\mathrm{R}=\mathrm{CH}\left(\mathrm{CH}_{3}\right) \mathrm{C}_{3} \mathrm{H}_{7}\right)$ & & \\
\hline $\mathrm{d}^{\prime \prime}$ & Lycopane & XVIII & & \\
\hline च & Contaminants (mostly phthalates) & & & \\
\hline
\end{tabular}

${ }^{\mathrm{a}} \mathrm{BP}=$ base peak.

rived from other DSDP sites (Fig. 12; Stein, 1986a, 1986b). Anoxic deep-water conditions in the North Atlantic during the $\mathrm{Ce}$ nomanian/Turonian are also suggested by several other authors (e.g., Brumsack, 1980; Tissot et al., 1980; Bralower and Thierstein, 1984; de Graciansky et al., 1984; Herbin et al., 1986; Simoneit, 1986b).

\section{Diagenesis of Organic Matter}

Vitrinite (huminite) reflectance measurements (Table 3) indicate that the (primary) organic matter in the sediments depos- ited on the Galicia continental margin is immature. The average value of about $0.3 \%$ reflectance precludes significantly deeper burial of the sediments and subsequent uplift or high heat flow at any time in the past in this area. The small depth interval studied does not allow the observance of major diagenetic trends.

On the molecular level, the signals of the organic matter sources and the bacterial reworking of the organic material during transport, settling, and early burial were probably more influential in determining the variability of composition in the samples studied than the diagenetic processes in the sediment column during subsidence. 

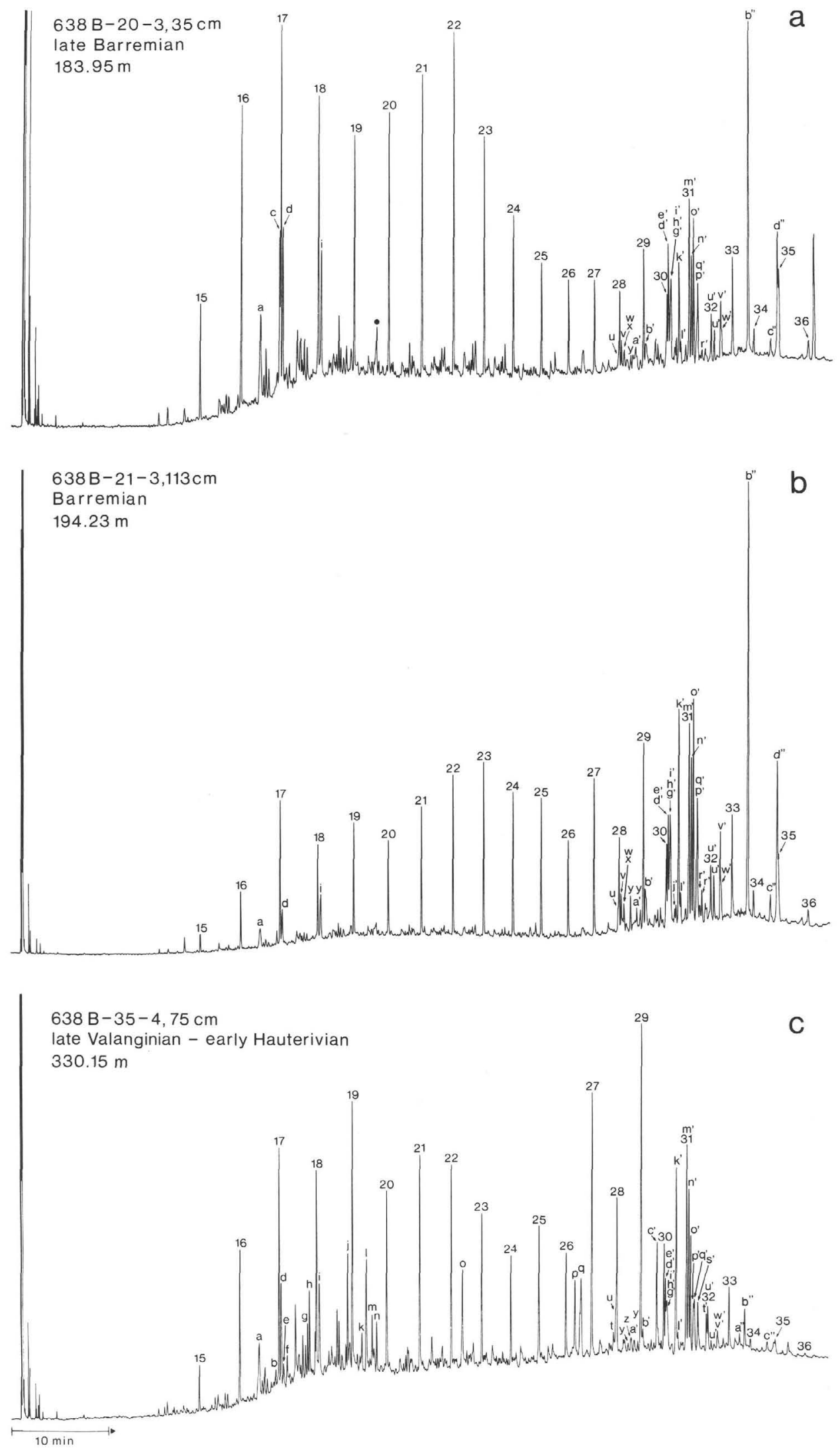

Figure 7. Capillary column gas chromatograms of the nonaromatic hydrocarbon fractions of selected sediment samples from Site 638. See Table 4 for identification of letter symbols. Numbers indicate $n$-alkanes. 
R. STEIN ET AL.
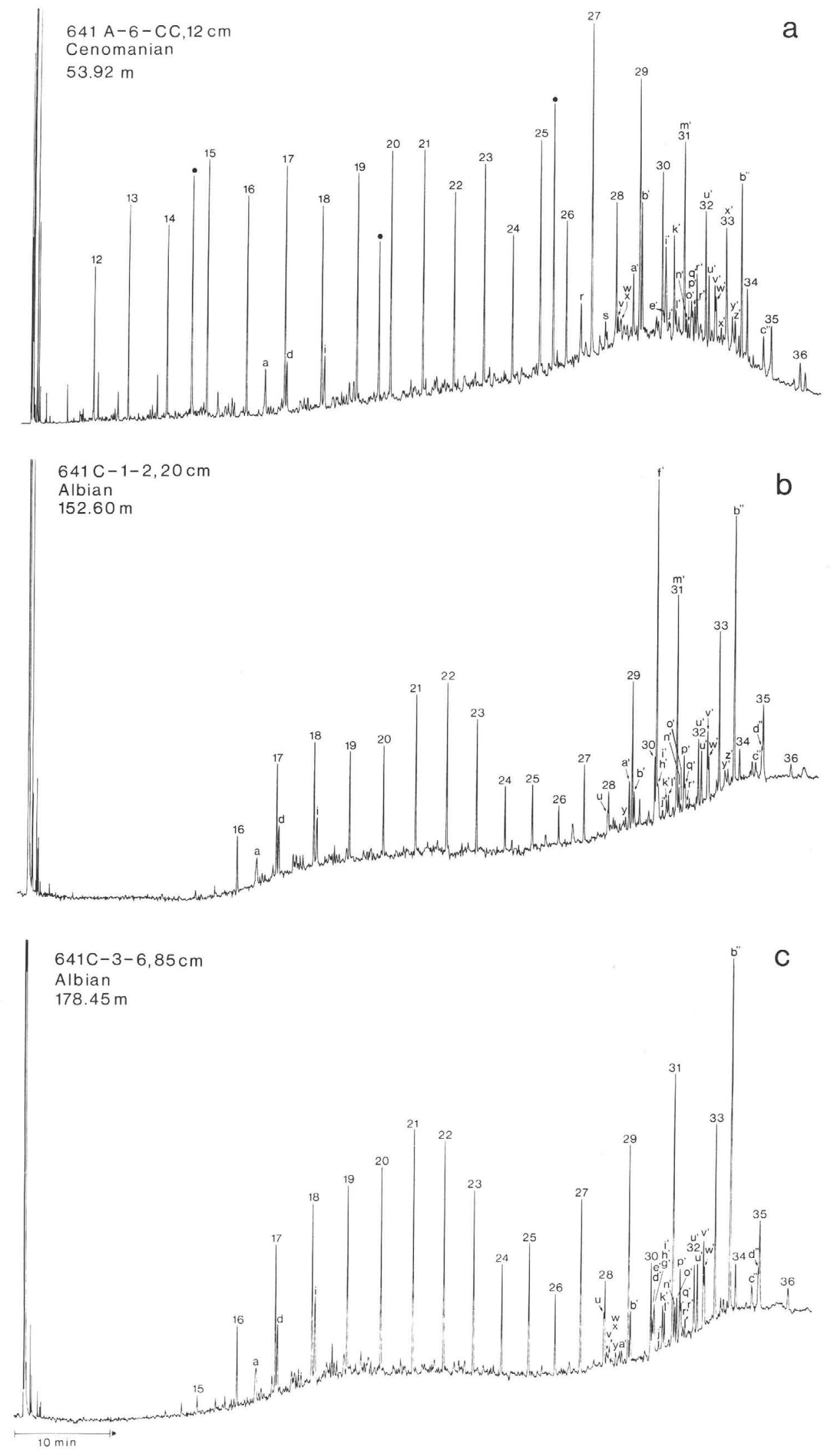

Figure 8. Capillary column gas chromatograms of the nonaromatic hydrocarbon fraction of selected sediment samples from Site 641 . See Table 4 for identification of letter symbols. Numbers indicate $n$ alkanes. 

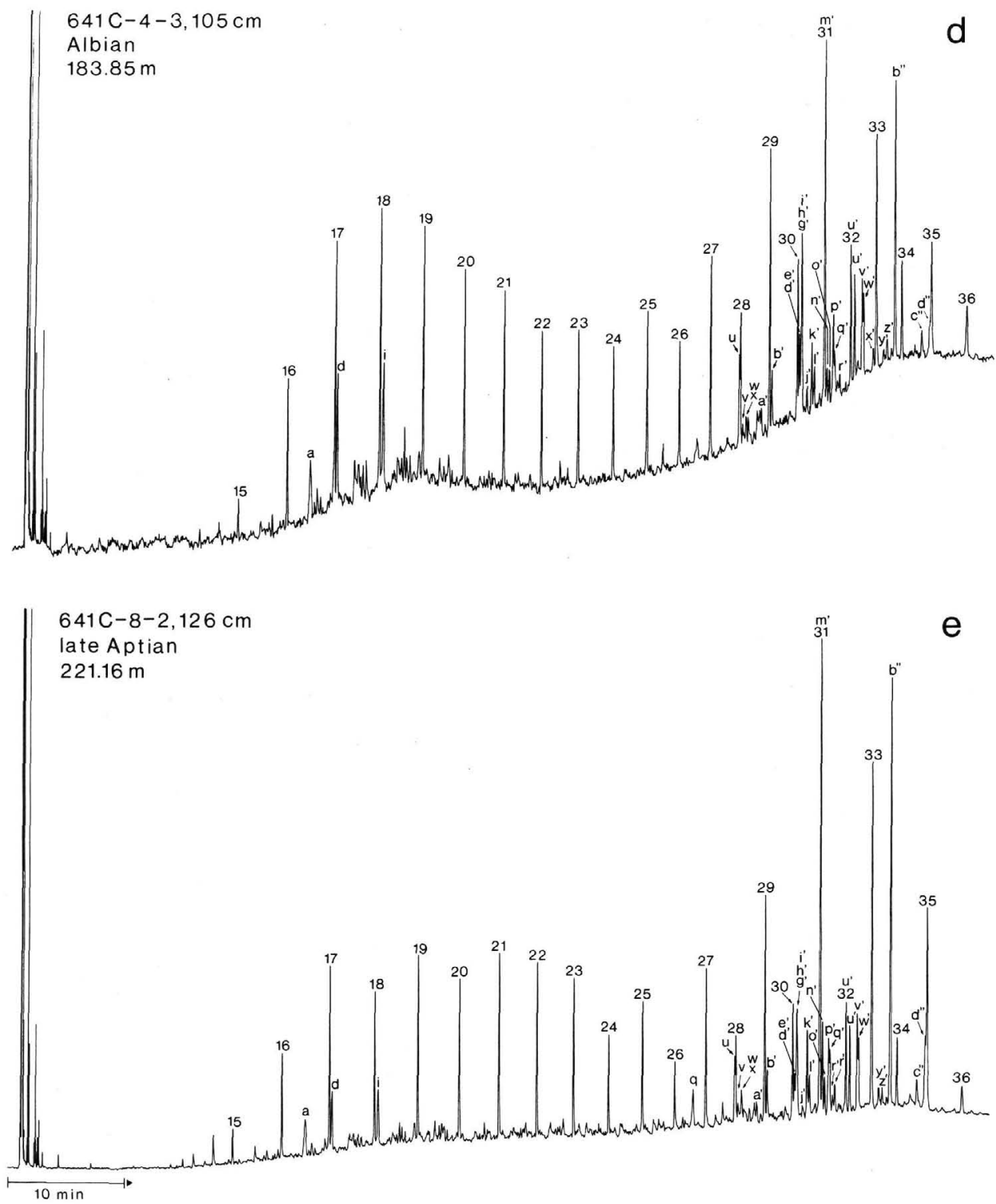

Figure 8 (continued).

\section{CONCLUSIONS}

The results of detailed organic geochemical investigations of the 25 Valanginian to Cenomanian samples from ODP Sites 638,640 , and 641 can be summarized as follows:

1. The TOC values show high-amplitude variations ranging between $0.1 \%$ and about $5 \%$. Near the Cenomanian/Turonian boundary, TOC values of more than $11 \%$ were recorded.

2. During the Valanginian to Albian, changes in the supply of terrigenous organic detritus were the main control of the accumulation of organic matter on the Galicia margin.

3. The Cenomanian/Turonian black shale is dominated by marine organic matter, probably resulting from a higher preservation rate as a result of anoxic deep-water conditions during that time.

4. Vitrinite reflectance values of less than $0.38 \%$ indicate the thermal immaturity of the primary organic matter. Reworked, redeposited, and more mature (vitrinite reflectance values of up to $1 \%$ ) organic matter is common in most sediment samples investigated.
5. The ODP Leg 103 organic geochemical data are in agreement with those recorded at nearby DSDP Site 398 and the general depositional history of organic matter in the North Atlantic based on other DSDP investigations.

\section{ACKNOWLEDGMENTS}

We would like to thank P. J. Müller for conducting the organic carbon analyses and Rock-Eval pyrolysis and M. Radke for conducting the extraction/liquid chromatography. We thank W. Benders, U. Disko, F.J. Keller, and K. Sellinghoff for technical assistance. Financial support by the Deutsche Forschungsgemeinschaft (Grant No. We 346-27) is gratefully acknowledged. This manuscript was reviewed by P. Meyers and B. Simoneit.

\section{REFERENCES}

Arthur, M. A., Dean, W. E., and Stow, D.A.V., 1984. Models for the deposition of Mesozoic-Cenozoic fine-grained organic-carbon-rich sediments in the deep sea. In Stow, D.A.V., and Piper, D.J.W. (Eds.), Fine-grained Sediments: Deep-Water Processes and Facies: Geol. Soc. Spec. Publ. London, 15:527-560.

Betzer, P. R., Showers, W. J., Laws, E. A., Winn, C. D., Ditullio, G. R., and Kroopnick, P. M., 1984. Primary productivity and particle 
fluxes on a transect of the equator at $153^{\circ} \mathrm{W}$ in the Pacific Ocean. Deep Sea Res., Part A, 31:1-11.

Bralower, T. J., and Thierstein, H. R., 1984. Low productivity and slow deep-water circulation in mid-Cretaceous oceans. Geology, 12:614618.

Brassell, S. C., Wardroper, A.M.K., Thomson, I. D., Maxwell, J. R., and Eglinton, G., 1981. Specific acyclic isoprenoids as biological markers of methanogenic bacteria in marine sediments. Nature, 290: 693-696.

Brumsack, H. J., 1980. Geochemistry of Cretaceous black shales from the Atlantic Ocean (DSDP Legs 11, 14, 36, and 41). Chem. Geol., $31: 1-25$.

Cornford, C., 1979. Organic petrography of Lower Cretaceous shales at DSDP Leg 47B, Site 398, Vigo Seamount, eastern North Atlantic. In Sibuet, J.-C., Ryan, W.B.F., et al., Init. Repts. DSDP, 47, Pt. 2: Washington (U.S. Govt. Printing Office), 523-528.

de Graciansky, P. C., Auffret, G. A., Dupeuble, P., Montadert, L., and Müller, C., 1979. Interpretation of depositional environments of the Aptian/Albian black shales on the north margin of the Bay of Biscay (DSDP Sites 400 and 402). In Montadert, L., Roberts, D., et al., Init. Repts. DSDP, 48: Washington (U.S. Govt. Printing Office), 877-907.

de Graciansky, P. C., Deroo, G., Herbin, J. P., Montadert, L., Müller, C., Schaaf, A., and Sigal, J., 1984. Ocean-wide stagnation episode in the Late Cretaceous. Nature, 308:346-349.

Demaison, G. J., and Moore, G. T., 1980. Anoxic environments and oil source bed genesis. AAPG Bull., 64:1179-1209.

Diester-Haass, L., 1983. Differentiation of high oceanic fertility in marine sediments caused by coastal upwelling and/or river discharge off northwest Africa during the late Quaternary. In Thiede, J., and Suess, E. (Eds.), Coastal Upwelling, Its Sedimentary Record, Part $B$ : New York (Plenum Press), 399-420.

Espitalié, J., Laporte, J. L., Madec, M., Marquis, F., Leplat, P., Paulet, J., and Boutefeu, A., 1977. Méthode rapide de charactérisation des roches-mere, de leur potentiel pétrolier et de leur degré d'évolution. Rev. Inst. Fr. Pet., 32:23-42.

Fischer, A. G., and Arthur, M. A., 1977. Secular variations in the pelagic realm. In Cook, H. E., and Enos, P. (Eds.), Deep Water Carbonate Environments: Spec. Publ. Soc. Econ. Paleontol. Mineral., 25:19-50.

Hallam, A., 1984. Continental humid and arid zones during the Jurassic and Cretaceous. Palaeogeogr., Palaeoclimatol., Palaeoecol., 47: 195-223.

Herbin, J. P., Montadert, L., Müller, C., Gomez, R., Thurow, J., and Wiedmann, J., 1986. Organic-rich sedimentation at the Cenomanian/Turonian boundary in oceanic and coastal basins in the North Atlantic and Tethys. In Summerhayes, C. P., and Shackleton, N. J. (Eds.), Proceedings of the "North Atlantic Paleoceanography" Meeting: Geol. Soc. Spec. Publ. London, 21:389-422.

Müller, P. J., and Suess, E., 1979. Productivity, sedimentation rate, and sedimentary organic carbon content in the oceans. I. Organic carbon preservation. Deep Sea Res., Part A, 26:1347-1362.

Raiswell, R., and Berner, R. A., 1987. Organic carbon losses during the burial and thermal maturation of normal marine shales. Terra Cognita, 7:195.

Radke, M., Sittardt, H. G., and Welte, D. H., 1978. Removal of soluble organic matter from rock samples with a flow-through extraction cell. Anal. Chem., 50:663-665.

Radke, M., Willsch, H., and Welte, D. H., 1980. Preparative hydrocarbon group type determination by automated medium pressure liquid chromatography. Anal. Chem., 52:191-220.

Rullkötter, J., and Mukhopadhyay, P. K., 1986. Comparison of Mesozoic carbonaceous claystones in the western and eastern North Atlantic (DSDP Legs 76, 79, and 93). In Summerhayes, C. P., and Shackleton, N. J. (Eds.), Proceedings of the "North Atlantic Pale- oceanography” Meeting: Geol. Soc. Spec. Publ. London, 21:377388.

Rullkötter, J., Vuchev, V., Hinz, K., Winterer, E. L., Baumgartner, P. O., Bradshaw, M. L., Channell, J.E.T., Jeffrezo, M., Jansa, L. F., Leckie, R. M., Moore, R. M., Schaftenaar, C., Steiger, T. H., and Wiegand, G. E., 1983. Potential deep sea petroleum source beds related to coastal upwelling. In Thiede, J., and Suess, E. (Eds.), Coastal Upwelling, Its Sedimentary Record, Part B: New York (Plenum Press), 467-483.

Schlanger, S. O., and Jenkyns, H. C., 1976. Cretaceous oceanic anoxic events: causes and consequences. Geol. Mijnbouw, 55:179-184.

Shipboard Scientific Party, 1987a. Site 638. In Boillot, G., Winterer, E. L., et al., Proc. ODP, Init. Repts., 103: College Station, TX (Ocean Drilling Program), 221-407.

1987b. Site 640. In Boillot, G., Winterer, E. L., et al., Proc. ODP, Init. Repts., 103: College Station, TX (Ocean Drilling Program), 533-569.

1987c. Site 641. In Boillot, G., Winterer, E. L., et al., Proc. ODP, Init. Repts., 103: College Station, TX (Ocean Drilling Program), 571-649.

Sibuet, J.-C., Ryan, W.B.F., et al., 1979. Init. Repts. DSDP, 47, Pt. 2: Washington (U.S. Govt. Printing Office).

Simoneit, B.R.T., 1986a. Cyclic terpenoids of the geosphere. In Johns, R. B. (Ed.), Biological Markers in the Sedimentary Record: Amsterdam (Elsevier).

1986b. Biomarker geochemistry of black shales from Cretaceous oceans, an overview. Mar. Geol., 70:9-41.

Simoneit, B.R.T., and Mazurek, M. A., 1979. Lipid geochemistry of Cretaceous sediments from Vigo Seamount, DSDP/IPOD Leg 47B. In Sibuet, J.-C., Ryan, W.B.F., et al., Init, Repts. DSDP, 47, Pt. 2: Washington (U.S. Govt. Printing Office), 565-570.

Simoneit, B.R.T., Mazurek, M. A., Brenner, S., Crisp, P. T., and Kaplan, I. R., 1979. Organic geochemistry of Recent sediments from Guaymas Basin, Gulf of California. Deep Sea Res., Part A, 26:879891.

Stach, E., Mackowsky, M. T., Teichmüller, M., Taylor, G. H., Chandra, D., and Teichmüller, R., 1982. Coal Petrology: Berlin (Verlag Gebrüder Bornträger).

Stein, R., 1985. Late Neogene changes of paleoclimate and paleoproductivity off northwest Africa (DSDP Site 397). Palaeogeogr., Palaeoclimatol., Palaeoecol., 49:47-59.

1986a. Organic carbon and sedimentation rate: further evidence for anoxic deep-water conditions in the Cenomanian/Turonian Atlantic Ocean. Mar. Geol., 72:199-209.

1986b. Surface-water paleoproductivity as inferred from sediments deposited in oxic and anoxic deep-water environments of the Mesozoic Atlantic Ocean. In Degens, E. T., Meyers, P. A., and Brassell, S. C. (Eds.), Biogeochemistry of Black Shales: Mitt. Geol. Paläontol. Inst. Univ. Hamburg, 60:55-70.

Stein, R., Rullkötter, J., and Welte, D. H., 1986. Accumulation of organic-carbon-rich sediments in the Late Jurassic and Cretaceous Atlantic Ocean: a synthesis. Chem. Geol., 56:1-32.

Tissot, B., Demaison, G., Masson, P., Delteil, J. R., and Combaz, A., 1980. Paleoenvironment and petroleum potential of middle Cretaceous black shales in Atlantic basins. AAPG Bull., 64:2051-2063.

Vail, P. R., Mitchum, R. M., Shipley, T. H., and Buffler, R. T., 1980. Unconformities of the North Atlantic. Philos. Trans. R. Soc. London $A, 294: 137-155$.

van Andel, T. H., Heath, G. R., and Moore, T. C., 1975. Cenozoic History and Paleoceanography of the Central Equatorial Pacific: Mem. Geol Soc. Am., 143.

Date of initial receipt: 11 February 1987

Date of acceptance: 21 July 1987

Ms 103B-158 
Table 5. Polyunsaturated and aromatic steroid hydrocarbons in the aromatic hydrocarbon fractions of ODP Leg 103 sediments (cf. Figs. 9 and 10).

\begin{tabular}{|c|c|c|c|c|}
\hline Number & Compound type & Series & Structure & Mass spectral data \\
\hline 1 & $\mathrm{C}_{28}$ steratriene & 1 & & $380\left(\mathrm{M}^{+}\right), 255$ \\
\hline 2 & $\mathrm{C}_{27}$ anthrasteroid, $14 \beta(\mathrm{H}), 20 \mathrm{~S}$ or $\mathrm{R}$ & 2 & $X I X, R=H$ & $366\left(\mathrm{M}^{+}\right), 211$ \\
\hline 3 & $\mathrm{C}_{27}$ anthrasteroid, $14 \beta(\mathrm{H}), 20 \mathrm{R}$ or $\mathrm{S}$ & 2 & $X I X, R=H$ & $366\left(\mathrm{M}^{+}\right), 211$ \\
\hline 4 & $\mathrm{C}_{28}$ steratetraene & 3 & & $378\left(\mathrm{M}^{+}\right), 253$ \\
\hline 5 & $\mathrm{C}_{27}$ A-ring monoaromatic steroid & 4 & $\mathrm{XX}, \mathrm{R}=\mathrm{H}$ & $366\left(\mathrm{M}^{+}\right), 211,158$ \\
\hline 6 & $\mathrm{C}_{27}$ steratetraene & 5 & & $364\left(\mathrm{M}^{+}\right), 211$ \\
\hline 7 & $\mathrm{C}_{29}$ steratriene & 1 & & $394\left(\mathrm{M}^{+}\right), 255$ \\
\hline 8 & $C_{27}$ anthrasteroid, $14 \alpha(H), 20 S$ or $R$ & 2 & $X X I, R=H$ & $366\left(\mathrm{M}^{+}\right), 211$ \\
\hline 9 & $\mathrm{C}_{28}$ steratetraene & 6 & & $378\left(\mathrm{M}^{+}\right), 211$ \\
\hline 10 & $\mathrm{C}_{27}$ anthrasteroid, $14 \alpha(\mathrm{H}), 20 \mathrm{R}$ or $\mathrm{S}$ & 2 & $\mathrm{XXI}, \mathbf{R}=\mathbf{H}$ & $366\left(\mathrm{M}^{+}\right), 211$ \\
\hline 11 & $\mathrm{C}_{28}$ anthrasteroid, $14 \beta(\mathrm{H}), 20 \mathrm{~S}$ or $\mathrm{R}$ & 2 & $\mathrm{XIX}, \mathrm{R}=\mathrm{CH}_{3}$ & $380\left(\mathrm{M}^{+}\right), 211$ \\
\hline 12 & $\mathrm{C}_{29}$ steratetraene & 3 & & $392\left(\mathrm{M}^{+}\right), 253$ \\
\hline 13 & $\mathrm{C}_{27}$ steratetraene (coelutes with 14 ) & $5 ?$ & & $364\left(\mathrm{M}^{+}\right)$ \\
\hline 14 & $\mathrm{C}_{28}$ steratetraene & 6 & & $378\left(\mathrm{M}^{+}\right), 211$ \\
\hline 15 & $\mathrm{C}_{28}$ A-ring monoaromatic steroid & 4 & $\mathrm{XX}, \mathrm{R}=\mathrm{CH}_{3}$ & $380\left(\mathrm{M}^{+}\right), 211,158$ \\
\hline 16 & $\mathrm{C}_{29}$ anthrasteroid, $14 \beta(\mathrm{H}), 20 \mathrm{~S}$ or $\mathrm{R}$ & 2 & $\mathrm{XIX}, \mathrm{R}=\mathrm{C}_{2} \mathrm{H}_{5}$ & $394\left(\mathrm{M}^{+}\right), 211$ \\
\hline 17 & $\mathrm{C}_{29}$ anthrasteroid, $14 \beta(\mathrm{H}), 20 \mathrm{~S}$ or $\mathrm{R}$ & 2 & $\mathrm{XIX}, \mathrm{R}=\mathrm{C}_{2} \mathrm{H}_{5}$ & $394\left(\mathrm{M}^{+}\right), 211$ \\
\hline 18 & $\mathrm{C}_{29}$ steratetraene & 6 & & $392\left(\mathrm{M}^{+}\right), 211$ \\
\hline 19 & $\mathrm{C}_{28}$ anthrasteroid, $14 \alpha(\mathrm{H}), 20 \mathrm{~S}$ or $\mathrm{R}$ & 2 & $\mathrm{XXI}, \mathrm{R}=\mathrm{CH}_{3}$ & $380\left(\mathrm{M}^{+}\right), 211$ \\
\hline 20 & $\mathrm{C}_{28}$ steratetraene & 6 & & $378\left(\mathrm{M}^{+}\right), 211$ \\
\hline 21 & $\mathrm{C}_{28}^{20}$ anthrasteroid, $14 \alpha(\mathrm{H}), 20 \mathrm{R}$ or $\mathrm{S}$ & 2 & $(\mathrm{XXI}), \mathrm{R}=\mathrm{CH}_{3}$ & $380\left(\mathrm{M}^{+}\right), 211$ \\
\hline 22 & $\mathrm{C}_{29}$ steratetraene & 6 & & $392\left(\mathrm{M}^{+}\right), 211$ \\
\hline 23 & $\mathrm{C}_{29}$ steratetraene & 6 & & $392\left(\mathrm{M}^{+}\right), 211$ \\
\hline 24 & $\mathrm{C}_{29}$ A-ring monoaromatic steroid & 4 & $\mathrm{XX}, \mathrm{R}=\mathrm{C}_{2} \mathrm{H}_{5}$ & $394\left(\mathrm{M}^{+}\right), 211,158$ \\
\hline 25 & $\mathrm{C}_{28}$ steratetraene & 7 & & $378\left(\mathrm{M}^{+}\right), 251$ \\
\hline 26 & $\mathrm{C}_{29}$ anthrasteroid, $14 \alpha(\mathrm{H}), 20 \mathrm{~S}$ or $\mathrm{R}$ & 2 & $\mathrm{XXI}, \mathrm{R}=\mathrm{C}_{2} \mathrm{H}_{5}$ & $394\left(\mathrm{M}^{+}\right), 211$ \\
\hline 27 & $\mathrm{C}_{29}$ anthrasteroid, $14 \alpha(\mathrm{H}), 20 \mathrm{R}$ or $\mathrm{S}$ & 2 & $\mathrm{XXI}, \mathrm{R}=\mathrm{C}_{2} \mathrm{H}_{5}$ & $394\left(\mathrm{M}^{+}\right), 211$ \\
\hline 28 & $\mathrm{C}_{29}$ steratetraene & 7 & & $392\left(\mathrm{M}^{+}\right), 251$ \\
\hline 29 & $\mathrm{C}_{29}$ steratetraene & 7 & & $392\left(\mathrm{M}^{+}\right), 251$ \\
\hline
\end{tabular}


R. STEIN ET AL.
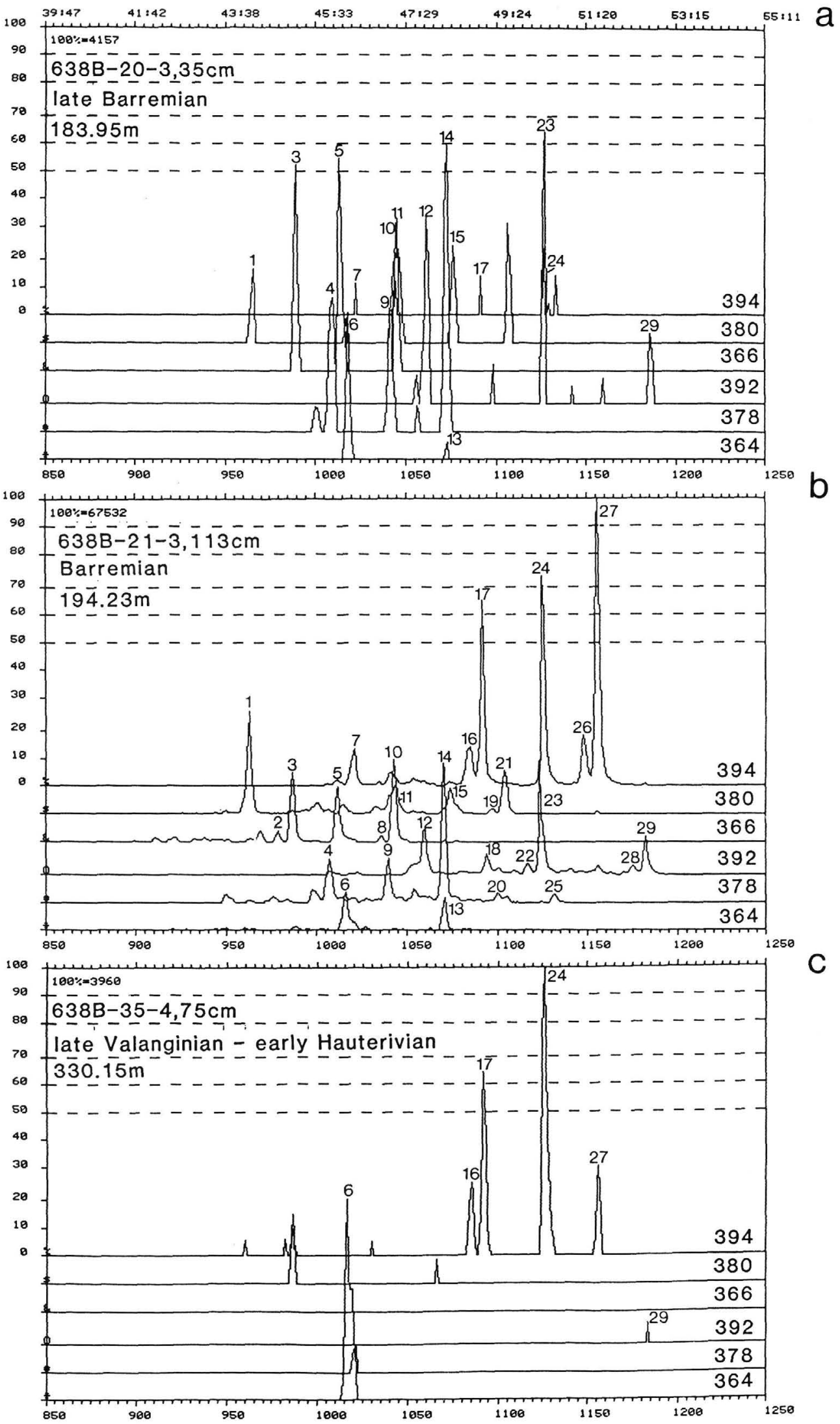

Figure 9. Mass fragmentograms of the molecular ions of $\mathrm{C}_{27}$ to $\mathrm{C}_{29}$ triunsaturated and tetraunsaturated steroid hydrocarbons in the aromatic hydrocarbon fractions of selected sediment samples from Site 638 . See Table 5 for compound identifications and mass spectral data. 


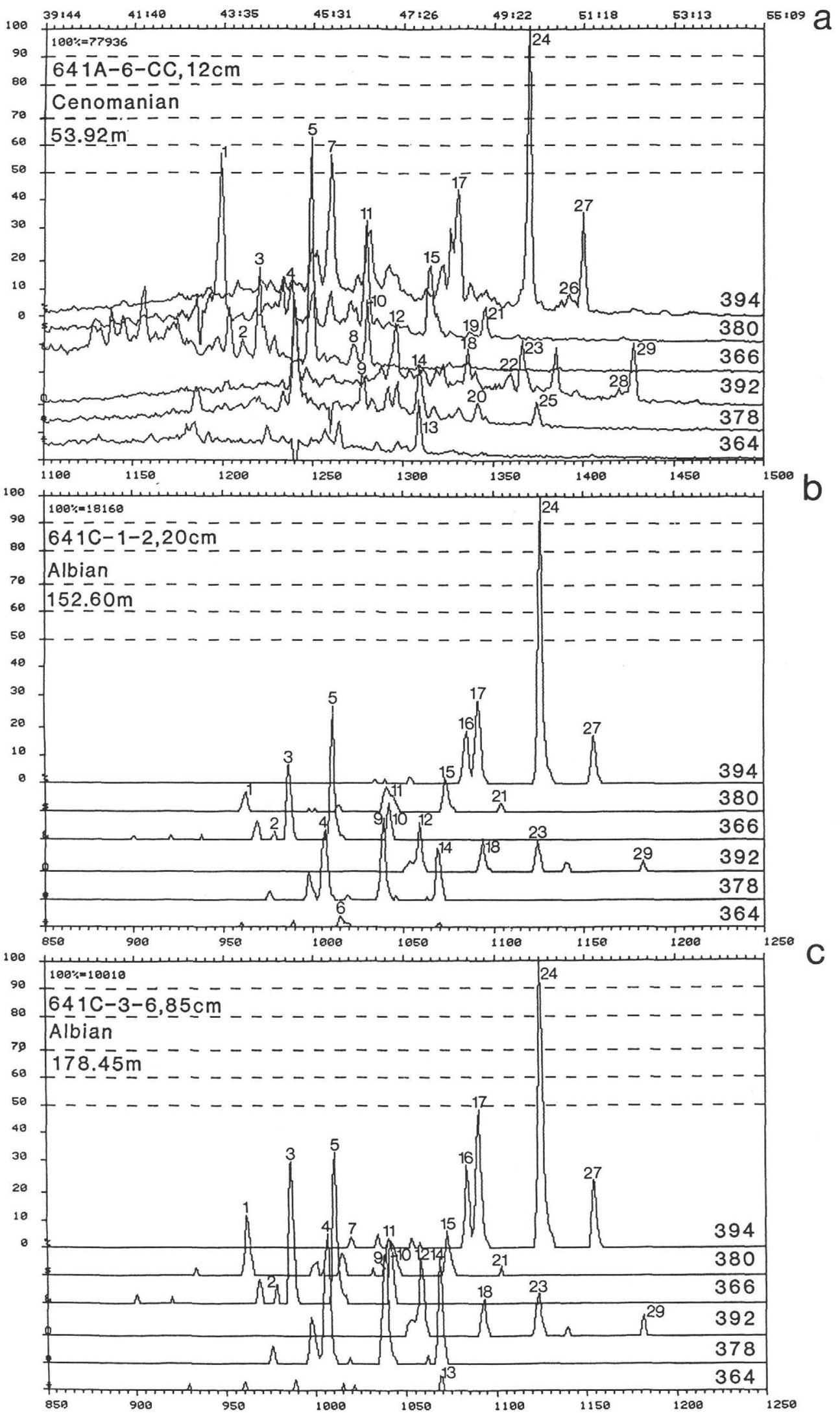

Figure 10. Mass fragmentograms of the molecular ions of $\mathrm{C}_{27}$ to $\mathrm{C}_{29}$ triunsaturated and tetraunsaturated steroid hydrocarbons in the aromatic hydrocarbon fractions of selected sediment samples from Site 641 . See Table 5 for compound identifications and mass spectral data. 


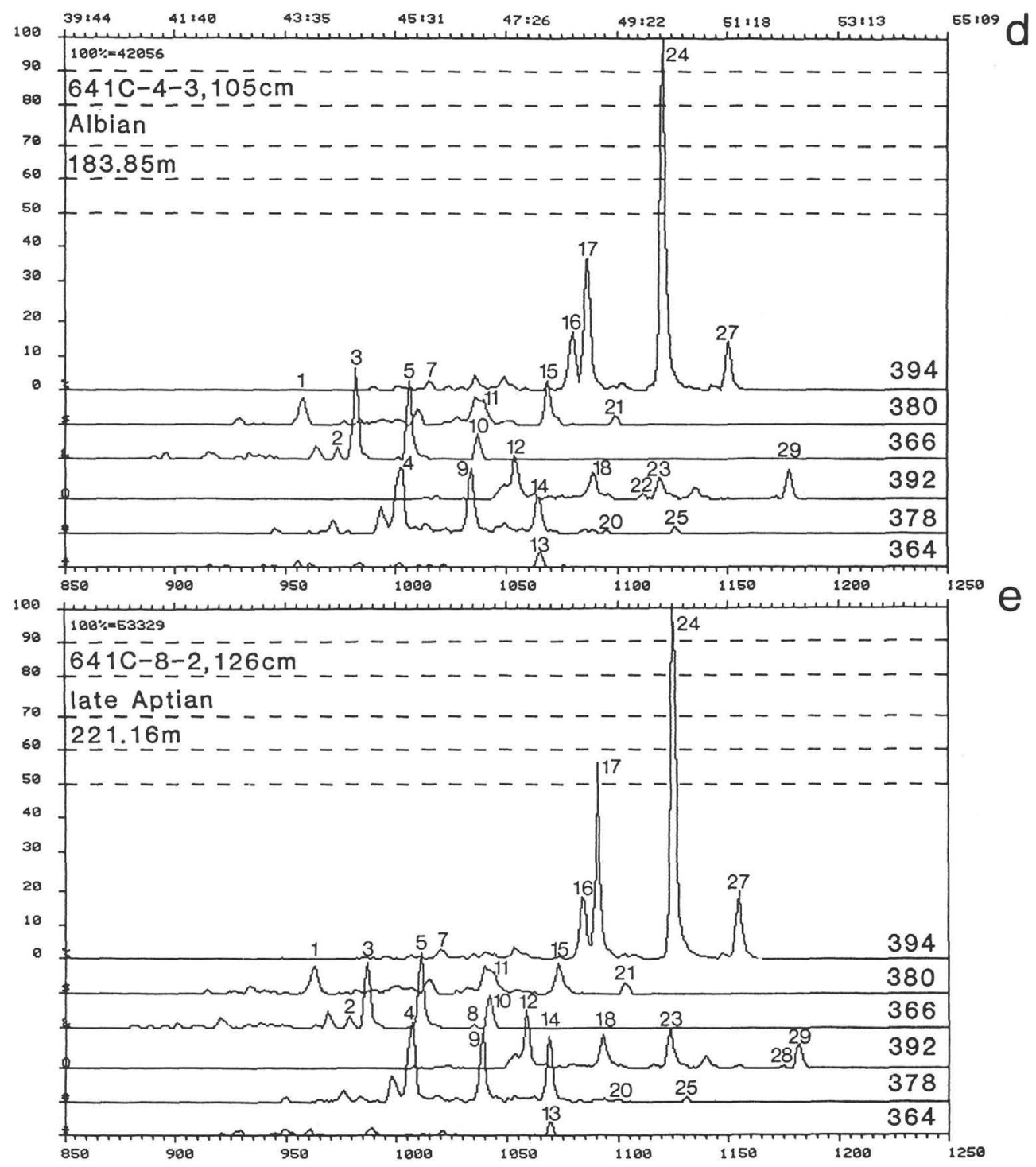

Figure 10 (continued). 


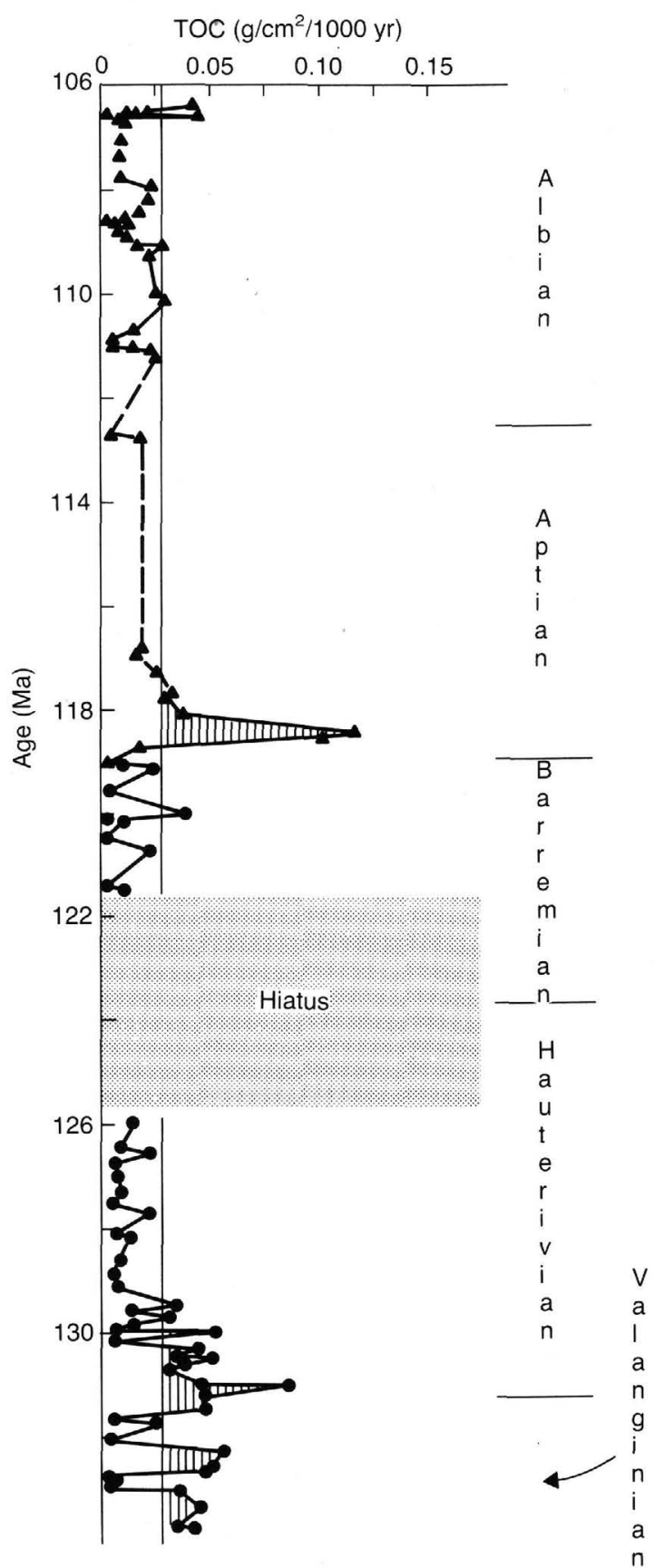

Figure 11. Accumulation rates of organic carbon. Solid triangles are data from Site 641, solid circles are data from Site 638. The dotted interval marks a hiatus. 


\section{R. STEIN ET AL.}

Table 6. Estimated paleoproductivity at Sites 638 and 641 . Ages and the estimated water depths, sedimentation rates, wet-bulk density, and porosity are from Shipboard Scientific Party (1987a, 1987c). The Valanginian to Albian productivity values are calculated using equation (1) from the text (Stein, 1986b), the Cenomanian value is calculated using equation (2) (Bralower and Thierstein, 1984). Samples from turbidites are marked by a cross; the data should be interpreted with caution.

\begin{tabular}{|c|c|c|c|c|c|c|c|c|}
\hline Site & Age & $\begin{array}{l}\text { Estimated } \\
\text { water } \\
\text { depth }(m)\end{array}$ & $\begin{array}{l}\text { Sedimentation } \\
\text { rate } \\
(\mathrm{cm} / 1000 \mathrm{yr})\end{array}$ & $\begin{array}{c}\text { Wet-bulk } \\
\text { density } \\
\left(\mathrm{g} / \mathrm{cm}^{3}\right)\end{array}$ & $\begin{array}{c}\text { Porosity } \\
(\%)\end{array}$ & $\begin{array}{c}\text { Total } \\
\text { organic } \\
\text { carbon } \\
(\%)\end{array}$ & $\begin{array}{c}\text { Marine } \\
\text { organic carbon } \\
(\% \text { TOC) }\end{array}$ & $\begin{array}{l}\text { Paleoproductivity } \\
\left(\mathrm{g} / \mathrm{m}^{2} / \mathrm{yr}\right)\end{array}$ \\
\hline $103-641 \mathrm{~A}-6 \mathrm{X}, \mathrm{CC}(12 \mathrm{~cm})$ & Cenomanian & 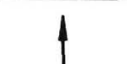 & 0.2 & & 1 & 11.6 & $\begin{array}{c}\mathrm{a}_{43} \\
\mathrm{~b}_{(91)}\end{array}$ & ${ }^{\mathrm{a}}<10$ \\
\hline $103-641 \mathrm{C}-1 \mathrm{R}, 20 \mathrm{~cm}$ & Albian & & & & & 1.64 & 11 & 60 \\
\hline $3 \mathrm{R}-6,85 \mathrm{~cm}$ & Albian & 2500 & 0.77 & 1.81 & 57 & 2.62 & 23 & 140 \\
\hline $4 \mathrm{R}-3,105 \mathrm{~cm}$ & Albian & & & & & 1.56 & 12 & 60 \\
\hline $4 \mathrm{R}-5,75 \mathrm{~cm}$ & Albian & & & & & 1.54 & 34 & 120 \\
\hline $8 \mathrm{R}-2,126 \mathrm{~cm}$ & Aptian & & 0.88 & & & 1.48 & 14 & 70 \\
\hline$+103-638 \mathrm{~B}-20 \mathrm{R}-3,35 \mathrm{~cm}$ & Aptian & & 1.16 & & $t$ & 1.51 & 35 & 150 \\
\hline $21 \mathrm{R}-3,113 \mathrm{~cm}$ & Barremian & 2300 & 1.16 & 2.00 & 50 & 2.24 & 22 & 140 \\
\hline $35 \mathrm{R}-4,75 \mathrm{~cm}$ & Hauterivian & & 3.30 & & & 1.82 & 2 & 25 \\
\hline
\end{tabular}

a Minimum amount of marine organic carbon.

b Maximum amount of marine organic carbon (i.e., if all bituminite in Table 3 is marine).

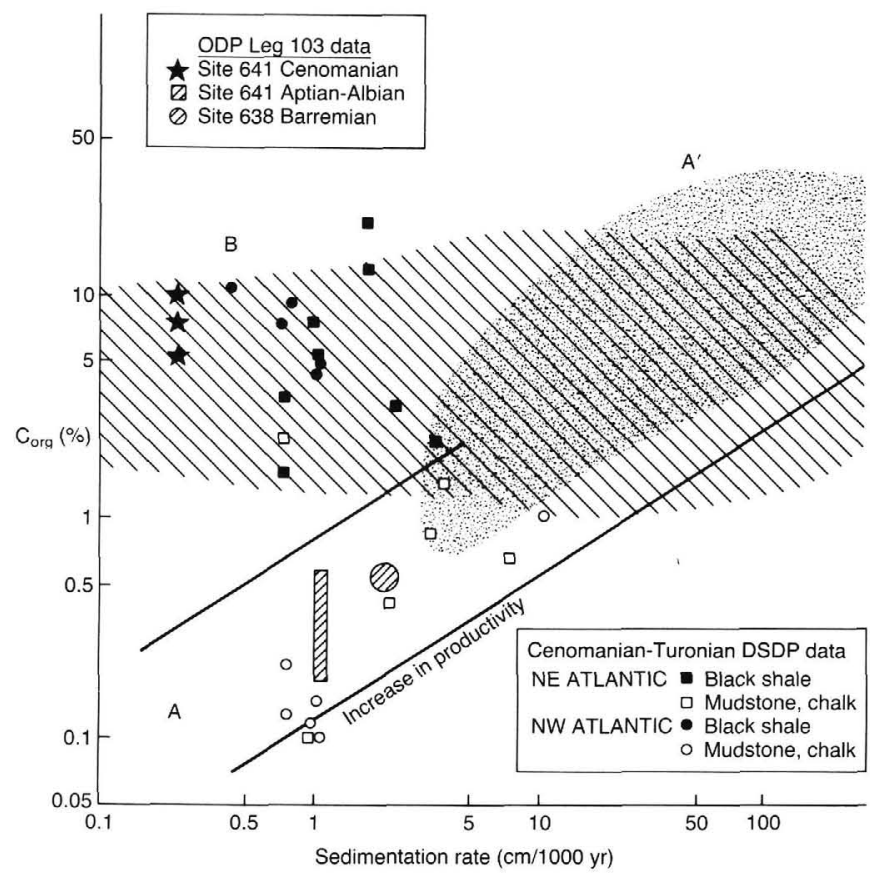

Figure 12. Correlation between (marine) organic carbon and sedimentation rates. The distinction between fields A, A', and B is based on data derived from Recent to Miocene sediments deposited in oxic environments (field A), high-productivity areas (field A'), and anoxic environments (field B) (Stein, 1986a). Solid symbols mark black shales, open symbols mark limestones-mudstones. The Cenomanian-Turonian sedimentation rates have been corrected for compaction (procedure in Stein, 1986a). 

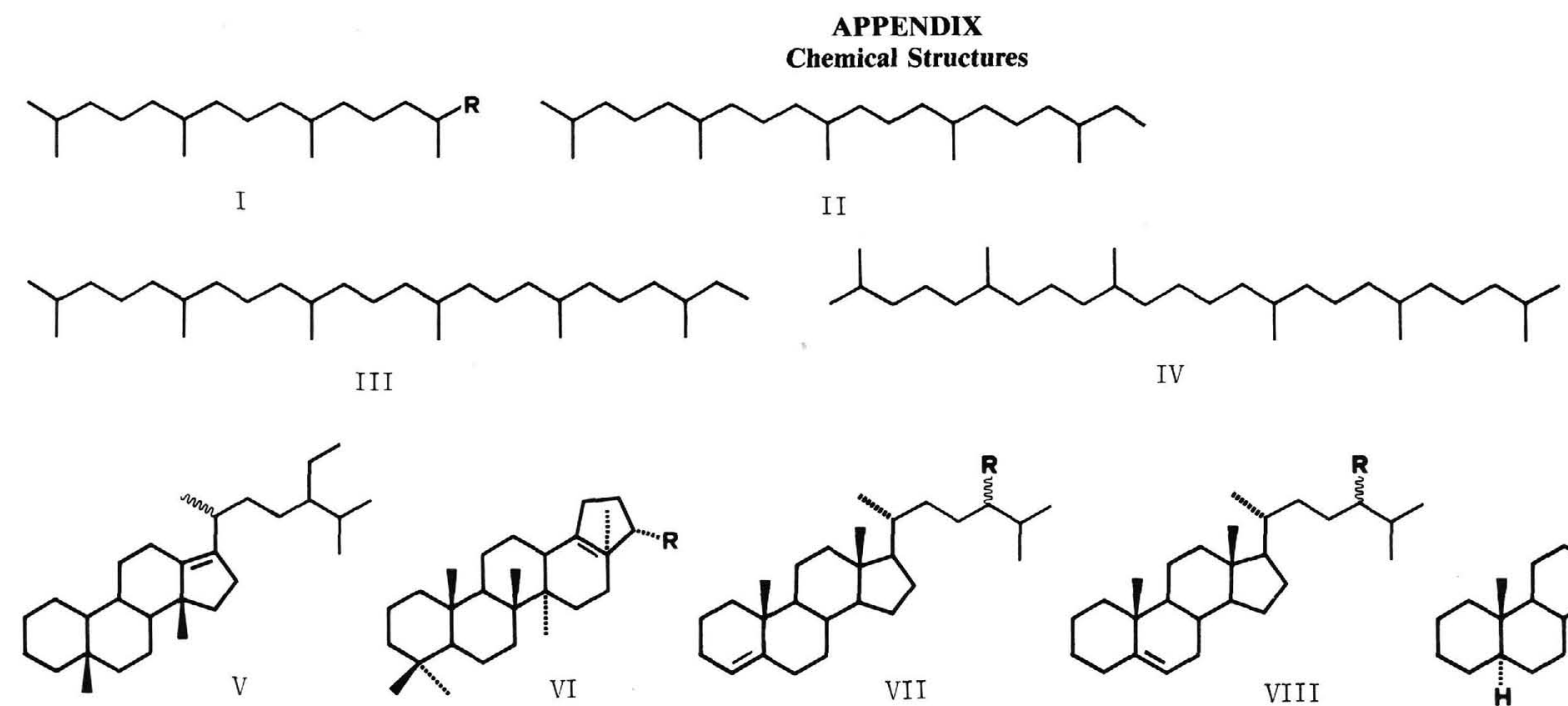<smiles>[R]C(CC[C@@H](C)[C@H]1CCC2C3CCC4=CCCC[C@]4(C)[C@H]3CC[C@]21C)C(C)C</smiles><smiles>[R]C(CC[C@@H](C)[C@H]1CCC2C3CC=C4CCCC[C@]4(C)[C@H]3CC[C@]21C)C(C)C</smiles><smiles>[R]C(C)C(C)CC[C@H](C)[C@H]1CCC2C3CC[C@H]4CCCC[C@]4(C)[C@H]3CC[C@]21C</smiles>

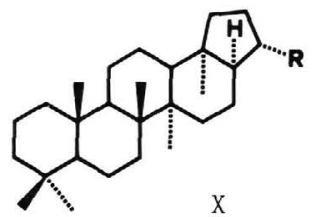

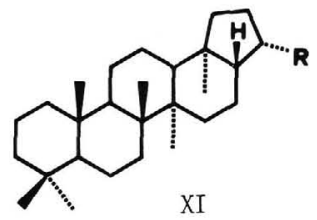

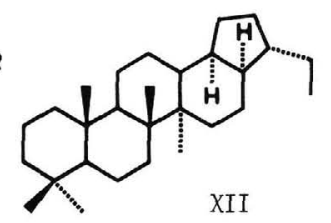

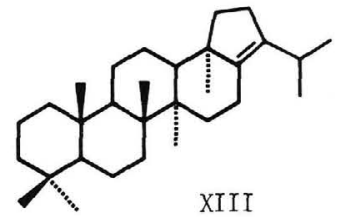

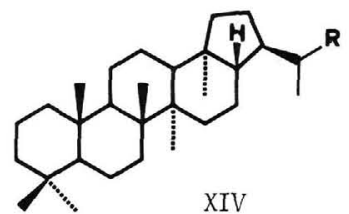<smiles>CC(C)C1CCC2C1CC[C@]1(C)C3=C(CCC21)[C@@]1(C)CCCC(C)(C)C1CC3</smiles>

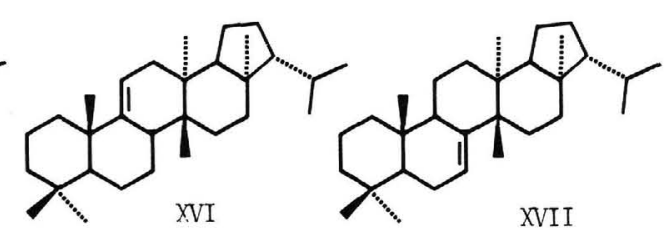<smiles>CC(C)CCCC(C)CCCC(C)CCCC(C)CCCCC(C)CCCC(C)CCCC(C)CCCC(C)C</smiles>

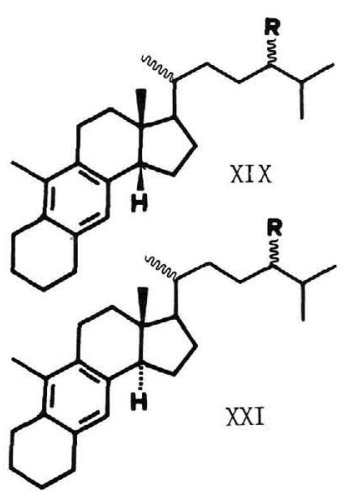<smiles>[X][M]C1CCC2C3CCc4c(C)cccc4C3CC[C@]12C[C@@H](C)CC[C@H]([R])C(C)C</smiles> 